Prepared in cooperation with the KANSAS DEPARTMENT OF HEALTH AND ENVIRONMENT

Sedimentation and Occurrence and Trends of Selected Nutrients, Other Chemical Constituents, and Cyanobacteria in Bottom Sediment, Clinton Lake, Northeast Kansas, 1977-2009

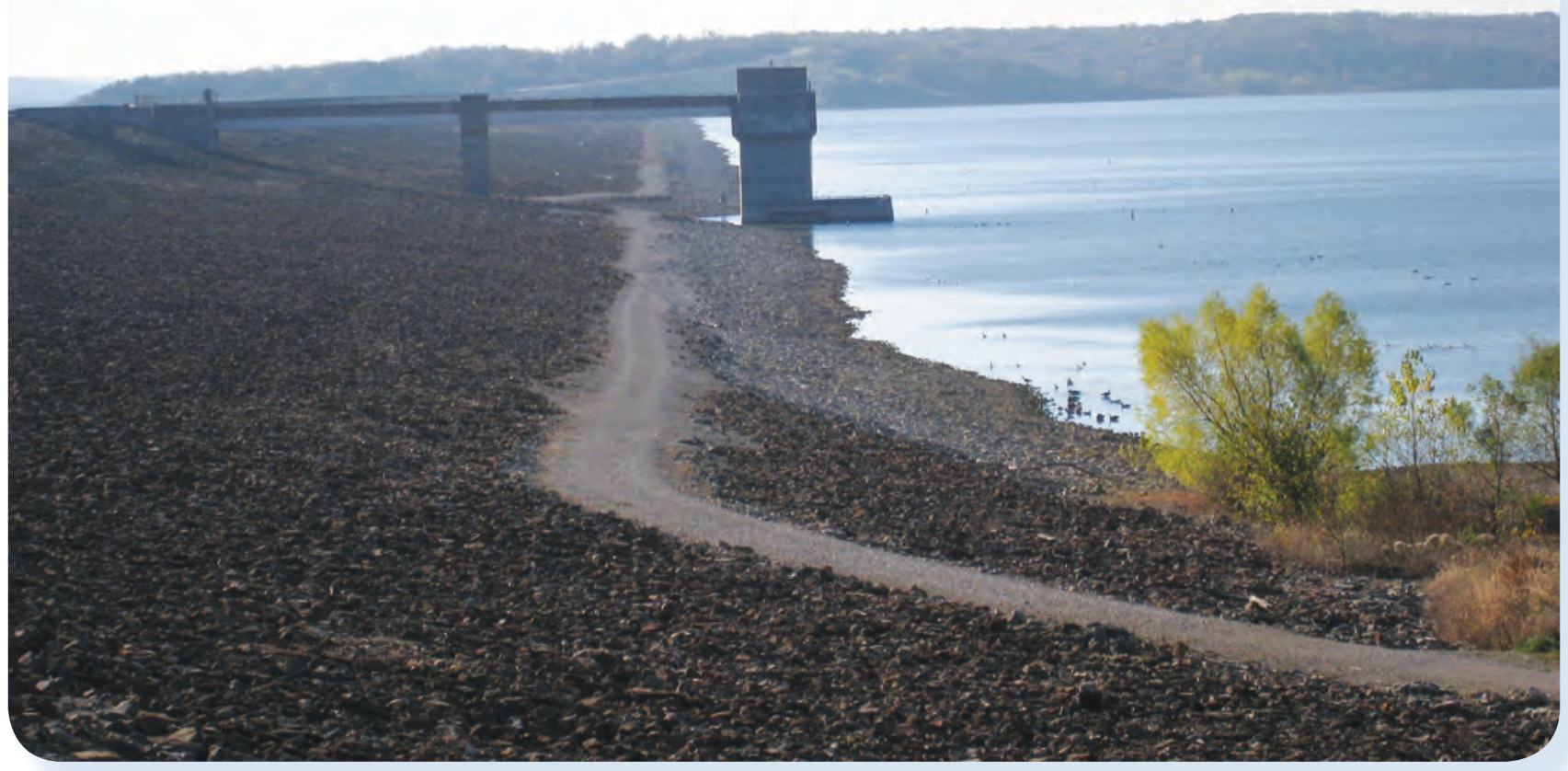

Scientific Investigations Report 2011-5037 


\section{Front cover.}

Clinton Lake dam looking along the west side of dam (photograph by Kyle E. Juracek, USGS).

\section{Back cover.}

Clinton Lake looking southwest (photograph by Kyle E. Juracek, USGS). 


\section{Sedimentation and Occurrence and Trends of Selected Nutrients, Other Chemical Constituents, and Cyanobacteria in Bottom Sediment, Clinton Lake, Northeast Kansas, 1977-2009}

By Kyle E. Juracek

Prepared in cooperation with the

KANSAS DEPARTMENT OF HEALTH AND ENVIRONMENT

Scientific Investigations Report 2011-5037 


\section{U.S. Department of the Interior \\ KEN SALAZAR, Secretary \\ U.S. Geological Survey \\ Marcia K. McNutt, Director}

\section{U.S. Geological Survey, Reston, Virginia: 2011}

For more information on the USGS - the Federal source for science about the Earth, its natural and living resources, natural hazards, and the environment, visit http://www.usgs.gov or call 1-888-ASK-USGS.

For an overview of USGS information products, including maps, imagery, and publications, visit http://www.usgs.gov/pubprod

To order this and other USGS information products, visit http://store.usgs.gov

Any use of trade, product, or firm names is for descriptive purposes only and does not imply endorsement by the U.S. Government.

Although this report is in the public domain, permission must be secured from the individual copyright owners to reproduce any copyrighted materials contained within this report.

Suggested citation: Juracek, K.E., 2011, Sedimentation and occurrence and trends of selected nutrients, other chemical constituents, and cyanobacteria in bottom sediment, Clinton Lake, northeast Kansas, 1977-2009: U.S. Geological Survey Scientific Investigations Report 2011-5037, 28 p. 


\section{Contents}

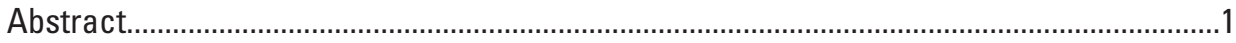

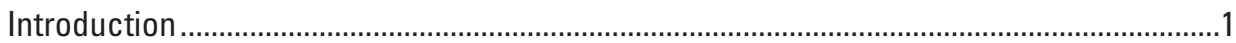

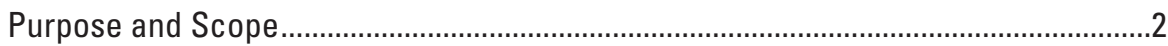

Description of Clinton Lake Basin ..............................................................................

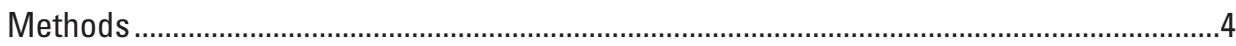

Estimation of Bottom-Sediment Volume, Mass, Mean Annual Net Deposition, and

Mean Annual Net Yield..............................................................................................

Sediment-Core Collection and Processing ...............................................................

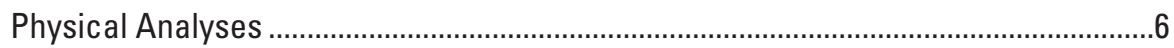

Chemical Analyses, Quality Control, and Age Dating .................................................6

Estimation of Nutrient Loads and Yields ...............................................................10

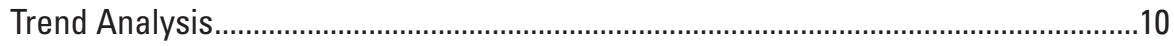

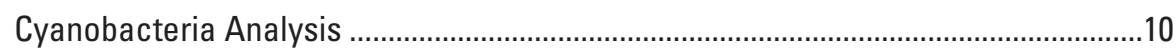

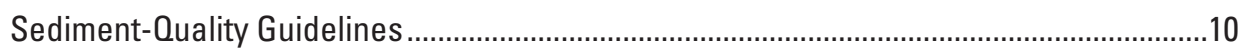

Background Information for Selected Chemical Constituents and Cyanobacteria ............11

Nutrients and Total Organic Carbon.........................................................................11

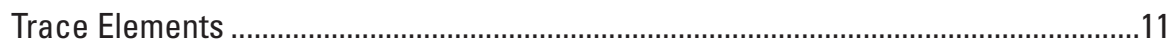

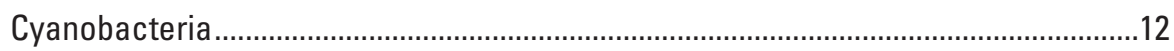

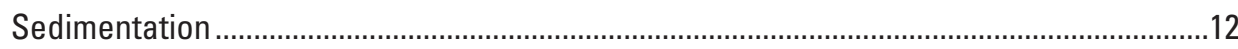

Occurrence of, and Trends in, Selected Chemical Constituents and Cyanobacteria.........13

Nutrients and Total Organic Carbon...........................................................................13

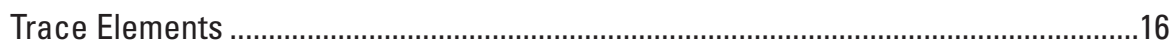

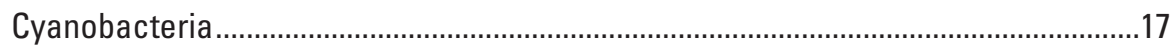

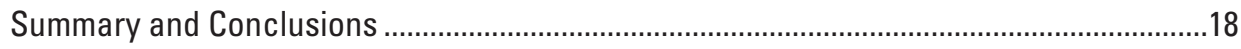

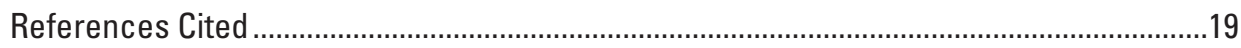

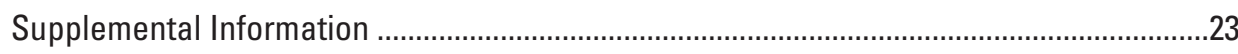

\section{Figures}

1. Map showing location of Clinton Lake Basin, Clinton Lake, and land use (2005) in Clinton Lake Basin, northeast Kansas ....................................................................................

2. Map showing location of bottom-sediment coring sites in Clinton Lake, northeast

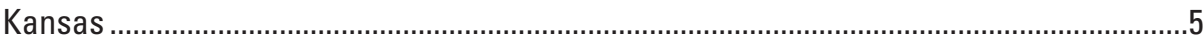

3. Graph showing variation in cesium-137 activity with depth of bottom-sediment samples collected from coring sites CLK-1, CLK-4, and CLK-6 in Clinton Lake, northeast Kansas, April 2009

4. Graph showing variation in total nitrogen concentrations with depth of bottom-sediment samples collected from coring sites CLK-1, CLK-4, and CLK-6 in Clinton Lake, northeast Kansas, April 2009

5. Graph showing variation in total phosphorus concentrations with depth of bottomsediment samples collected from coring sites CLK-1, CLK-4, and CLK-6 in Clinton Lake, northeast Kansas, April 2009

6. Graph showing variation in cyanobacterial akinete abundance with depth of bottomsediment samples collected from coring site CLK-1 in Clinton Lake, northeast Kansas, April 2009 


\section{Tables}

1. Chemical analyses for bottom-sediment samples from Clinton Lake, northeast Kansas, 2009.

2. Relative percentage differences for constituent concentrations in split-replicate samples from bottom sediment cores from Clinton Lake, northeast Kansas

3. Sediment-quality guidelines for selected trace elements and associated bioaccumula-

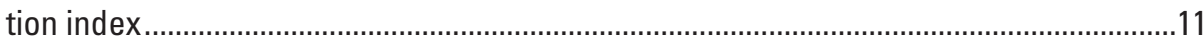

4. Sediment yield, precipitation, and land use for selected reservoir basins in Kansas ....13

5. Results of trend tests on concentrations of selected chemical constituents in bottomsediment samples collected from coring sites CLK-1, CLK-4, and CLK-6 in Clinton Lake, northeast Kansas, April 2009

6. Chlorophyll-a concentrations in Clinton Lake, northeast Kansas, 1979-2009..................18

\section{Supplemental Information}

A1. Latitude and longitude coordinates, water depth, estimated penetration depth, length of recovered core, and estimated recovery percentage for bottom-sediment coring sites at Clinton Lake, northeast Kansas

A2. Estimated bulk density of bottom sediment at coring sites in Clinton Lake, northeast Kansas.

A3. Percentage of silt and clay and constituent concentrations for bottom-sediment samples collected from coring site CLK-1 in Clinton Lake, northeast Kansas, April 2009

A4. Percentage of silt and clay and constituent concentrations for bottom-sediment samples collected from coring site CLK-4 in Clinton Lake, northeast Kansas, April 2009

A5. Percentage of silt and clay and constituent concentrations for bottom-sediment samples collected from coring site CLK-6 in Clinton Lake, northeast Kansas, April 2009 
Conversion Factors, Abbreviations, and Datum

\begin{tabular}{|c|c|c|}
\hline Multiply & By & To obtain \\
\hline \multicolumn{3}{|c|}{ Length } \\
\hline centimeter $(\mathrm{cm})$ & 0.3937 & inch (in.) \\
\hline foot $(\mathrm{ft})$ & 0.3048 & meter $(\mathrm{m})$ \\
\hline inch (in.) & 2.54 & centimeter $(\mathrm{cm})$ \\
\hline mile (mi) & 1.609 & kilometer $(\mathrm{km})$ \\
\hline millimeter (mm) & 0.03937 & inch (in.) \\
\hline \multicolumn{3}{|c|}{ Area } \\
\hline acre & 4,047 & square meter $\left(\mathrm{m}^{2}\right)$ \\
\hline acre & 0.4047 & hectare (ha) \\
\hline acre & 0.004047 & square kilometer $\left(\mathrm{km}^{2}\right)$ \\
\hline square foot $\left(\mathrm{ft}^{2}\right)$ & 0.09290 & square meter $\left(\mathrm{m}^{2}\right)$ \\
\hline square mile $\left(\mathrm{mi}^{2}\right)$ & 259.0 & hectare (ha) \\
\hline square mile $\left(\mathrm{mi}^{2}\right)$ & 2.590 & square kilometer $\left(\mathrm{km}^{2}\right)$ \\
\hline \multicolumn{3}{|c|}{ Volume } \\
\hline acre-foot (acre-ft) & 1,233 & cubic meter $\left(\mathrm{m}^{3}\right)$ \\
\hline cubic centimeter $\left(\mathrm{cm}^{3}\right)$ & 0.06102 & cubic inch $\left(\mathrm{in}^{3}\right)$ \\
\hline cubic foot $\left(\mathrm{ft}^{3}\right)$ & 0.02832 & cubic meter $\left(\mathrm{m}^{3}\right)$ \\
\hline \multicolumn{3}{|c|}{ Flow rate } \\
\hline cubic foot per second $\left(\mathrm{ft}^{3} / \mathrm{s}\right)$ & 0.02832 & cubic meter per second $\left(\mathrm{m}^{3} / \mathrm{s}\right)$ \\
\hline \multicolumn{3}{|c|}{ Mass } \\
\hline gram $(g)$ & 0.03527 & ounce (oz) \\
\hline milligram per kilogram (mg/kg) & 1.0 & part per million (ppm) \\
\hline pound (lb) & 0.4536 & kilogram $(\mathrm{kg})$ \\
\hline \multicolumn{3}{|c|}{ Density } \\
\hline gram per cubic centimeter $\left(\mathrm{g} / \mathrm{cm}^{3}\right)$ & 62.43 & pound per cubic foot $\left(\mathrm{lb} / \mathrm{ft}^{3}\right)$ \\
\hline pound per cubic foot $\left(\mathrm{lb} / \mathrm{ft}^{3}\right)$ & 16.02 & kilogram per cubic meter $\left(\mathrm{kg} / \mathrm{m}^{3}\right)$ \\
\hline
\end{tabular}

Temperature in degrees Celsius $\left({ }^{\circ} \mathrm{C}\right)$ may be converted to degrees Fahrenheit $\left({ }^{\circ} \mathrm{F}\right)$ as follows:

${ }^{\circ} \mathrm{F}=\left(1.8 x^{\circ} \mathrm{C}\right)+32$

Temperature in degrees Fahrenheit $\left({ }^{\circ} \mathrm{F}\right)$ may be converted to degrees Celsius $\left({ }^{\circ} \mathrm{C}\right)$ as follows:

${ }^{\circ} \mathrm{C}=\left({ }^{\circ} \mathrm{F}-32\right) / 1.8$

Horizontal coordinate information is referenced to the North American Datum of 1983 (NAD 83).

Elevation information is referenced to the National Geodetic Vertical Datum of 1929 (NGVD29).

\section{Acknowledgments}

This study was made possible, in part, by support from the Kansas Department of Health and Environment and the Kansas State Water Plan Fund. The author gratefully acknowledges topographic and bathymetric information provided by the U.S. Army Corps of Engineers and the Kansas Biological Survey as well as water-quality data provided by the Kansas Department of Health and Environment. 



\title{
Sedimentation and 0ccurrence and Trends of Selected Nutrients, Other Chemical Constituents, and Cyanobacteria in Bottom Sediment, Clinton Lake, Northeast Kansas, 1977-2009
}

\author{
By Kyle E. Juracek
}

\section{Abstract}

A combination of available bathymetric-survey information and bottom-sediment coring was used to investigate sedimentation and the occurrence of selected nutrients (total nitrogen and total phosphorus), organic and total carbon, 25 trace elements, cyanobacterial akinetes, and the radionuclide cesium-137 in the bottom sediment of Clinton Lake, northeast Kansas. The total estimated volume and mass of bottom sediment deposited from 1977 through 2009 in the conservation (multi-purpose) pool of the reservoir was 438 million cubic feet and 18 billion pounds, respectively. The estimated sediment volume occupied about 8 percent of the conservation-pool, water-storage capacity of the reservoir. Sedimentation in the conservation pool has occurred about 70 percent faster than originally projected at the time the reservoir was completed. Water-storage capacity in the conservation pool has been lost to sedimentation at a rate of about 0.25 percent annually. Mean annual net sediment deposition since 1977 in the conservation pool of the reservoir was estimated to be 563 million pounds per year. Mean annual net sediment yield from the Clinton Lake Basin was estimated to be 1.5 million pounds per square mile per year. Typically, the bottom sediment sampled in Clinton Lake was at least 99 percent silt and clay.

The mean annual net loads of total nitrogen and total phosphorus deposited in the bottom sediment of Clinton Lake were estimated to be 1.29 million pounds per year and 556,000 pounds per year, respectively. The estimated mean annual net yields of total nitrogen and total phosphorus from the Clinton Lake Basin were 3,510 pounds per square mile per year and 1,510 pounds per square mile per year, respectively. Throughout the history of Clinton Lake, total nitrogen concentrations in the deposited sediment generally were uniform and indicated consistent inputs to the reservoir over time. Likewise, total phosphorus concentrations in the deposited sediment generally were uniform. Although, for two of three coring sites, a possible positive trend in phosphorus deposition was indicated. The Wakarusa River possibly was a larger contributor of nitrogen and phosphorus to Clinton Lake than was Rock Creek. As a principal limiting factor for primary production in most freshwater environments, phosphorus is of particular importance because increased inputs can contribute to accelerated reservoir eutrophication and the production of algal toxins and taste-and-odor compounds.

Trace-element concentrations in the bottom sediment of Clinton Lake generally were uniform over time. As is typical for eastern Kansas reservoirs, arsenic, chromium, and nickel concentrations typically exceeded the threshold-effects guidelines, which represent the concentrations above which toxic biological effects occasionally occur. Zinc concentrations frequently exceeded the threshold-effects guideline. Traceelement concentrations did not exceed the probable-effects guidelines (available for eight trace elements), which represent the concentrations above which toxic biological effects usually or frequently occur.

Cyanobacterial akinetes (cyanobacteria resting stage) in the bottom sediment of Clinton Lake, combined with historical water-quality data on chlorophyll-a and total phosphorus concentrations, indicated that the reservoir likely has been eutrophic throughout most of its history. A statistically significant increase in cyanobacterial akinetes in the bottom sediment indicated that Clinton Lake may have become more eutrophic over the life of the reservoir. The increase in cyanobacterial akinetes may, in part, be related to a possible increase in total phosphorus concentrations.

\section{Introduction}

Benefits provided by reservoirs include flood control, water supply, recreation, and habitat for fish and wildlife. Effective management of reservoirs requires several types of information including water quality, sedimentation, and sediment quality.

Water-quality information is needed to determine the suitability of water in a reservoir for meeting various needs. Trends in water quality are useful for describing the overall 
effect of human activity in a reservoir basin, for providing an indication of the effectiveness of implemented regulatory decisions and changes in land-management practices, and for providing a warning of potential future water-quality problems.

Information on the volume and quality of sediment deposited in a reservoir also is important. Ongoing sedimentation reduces the water-storage capacity of, and negatively affects the benefits provided by, a reservoir. Sediment quality is an important environmental concern because sediment may act as a sink for water-quality constituents and, under certain conditions, as a source of constituents to the overlying water column and biota (Forstner and Wittmann, 1981; Baudo and others, 1990; Zoumis and others, 2001). Sediment-associated constituents of concern include nutrients (for example, phosphorus), trace elements, several pesticides, and polychlorinated biphenyls (PCBs) (Wetzel, 2001; Agency for Toxic Substances and Disease Registry, 2010). Once in the food chain, some sediment-derived constituents may pose an even greater concern because of bioaccumulation (Pais and Jones, 1997; Smol, 2002). An analysis of reservoir bottom sediment can provide historical information on sediment deposition as well as the occurrence of sediment-bound constituents. Such information may be used to partly reconstruct historical sediment-quality and water-quality records and to determine a present-day baseline with which to evaluate long-term changes in reservoir sediment and water quality that may be related to changes in human activity in the basin (Charles and Hites, 1987; Van Metre and Callender, 1996; Van Metre and Mahler, 2004; Juracek and Ziegler, 2006).

Clinton Lake is a Federal impoundment on the Wakarusa River in Douglas County, northeast Kansas (fig. 1). The reservoir officially was completed in 1977 by the U.S. Army Corps of Engineers (USACE) with an original design life of 100 years (U.S. Army Corps of Engineers, 1979). The reservoir is used for several purposes including flood control, water supply, recreation, water-quality control, and fish and wildlife (Susanna Gehrt, U.S. Army Corps of Engineers, written commun., 2010). In 1977, Clinton Lake had an original surface area of about 7,010 acres and a water-storage capacity of about 129,200 acre- $\mathrm{ft}$ (acre-feet) at the conservationpool (multi-purpose) elevation of $875.5 \mathrm{ft}$ (feet) above the National Geodetic Vertical Datum of 1929 (NGVD29) (U.S. Army Corps of Engineers, 1979). In 1991, the surface area and water-storage capacity at the conservation-pool elevation were about 7,120 acres and 125,300 acre-ft, respectively. The increase in surface area may be a result of erosion in the floodpool part of the reservoir and (or) inaccuracies in the reservoir surveys (Stephen Spaulding, U.S. Army Corps of Engineers, written commun., 2007). Based on a bathymetric survey completed in 2009 by the Kansas Biological Survey (KBS), water-storage capacity at the conservation-pool elevation was about 119,100 acre-ft (Kansas Biological Survey, 2010). The decrease in storage capacity is the result of ongoing sedimentation. Since 1977, the reservoir has lost an estimated 8 percent of its conservation-pool storage capacity. The estimated sedimentation rate of 324 acre-ft per year is about 70 percent larger than the sedimentation rate (190 acre-ft per year) that originally was projected for the conservation pool by USACE at the time the reservoir was completed (Kansas Water Office, 2010). Thus, the reservoir is filling with sediment faster than originally anticipated. As sedimentation continues, the ability of Clinton Lake to serve its various purposes will decline. Presently (2010), 81 percent of the conservation-pool storage is water-supply storage (Cheryl Buttenhoff, Kansas Water Office, oral commun., 2010).

In 1998, Clinton Lake was listed under Section 303(d) of the Federal Clean Water Act of 1972 for eutrophication (Kansas Department of Health and Environment, 2010). A eutrophic lake contains nutrient-rich water and supports high biotic productivity (Cole, 1994). Typically, eutrophic lakes support algal growth that, if excessive, can cause taste-and-odor problems for water suppliers. Also, excessive algal growth may be detrimental to aquatic life and limit recreational use of a lake.

The 303(d) list is a priority list that identifies water bodies that do not meet water-quality standards that are based on the use of the water bodies. For each impaired water body on the 303(d) list, a State is required by the Federal Clean Water Act to develop a total maximum daily load (TMDL), which is an estimate of the maximum pollutant load (material transported during a specified time period) from point and nonpoint sources that a receiving water can accept without exceeding water-quality standards (U.S. Environmental Protection Agency, 1991).

To provide information in support of the TMDL process, a 2-year study by the U.S. Geological Survey (USGS), in cooperation with the Kansas Department of Health and Environment (KDHE), was begun in 2008 to investigate sedimentation in Clinton Lake as well as the deposition of selected chemical constituents and cyanobacterial akinetes. The specific study objectives were to:

1. Estimate the volume, mass, mean annual net deposition, and mean annual net yield of sediment for the reservoir;

2. Determine the occurrence and trends of selected waterquality constituents in the bottom sediment of the reservoir;

3. Determine the mean annual net loads and yields of selected nutrients from the basin to the reservoir;

4. Assess the quality of the bottom sediment with respect to available guidelines; and

5. Determine the occurrence of cyanobacterial akinetes in the bottom sediment as an indication of eutrophication over the life of the reservoir.

\section{Purpose and Scope}

The purpose of this report is to present the results of the USGS study to estimate sedimentation and to determine the occurrence of, and temporal trends in, selected chemical 

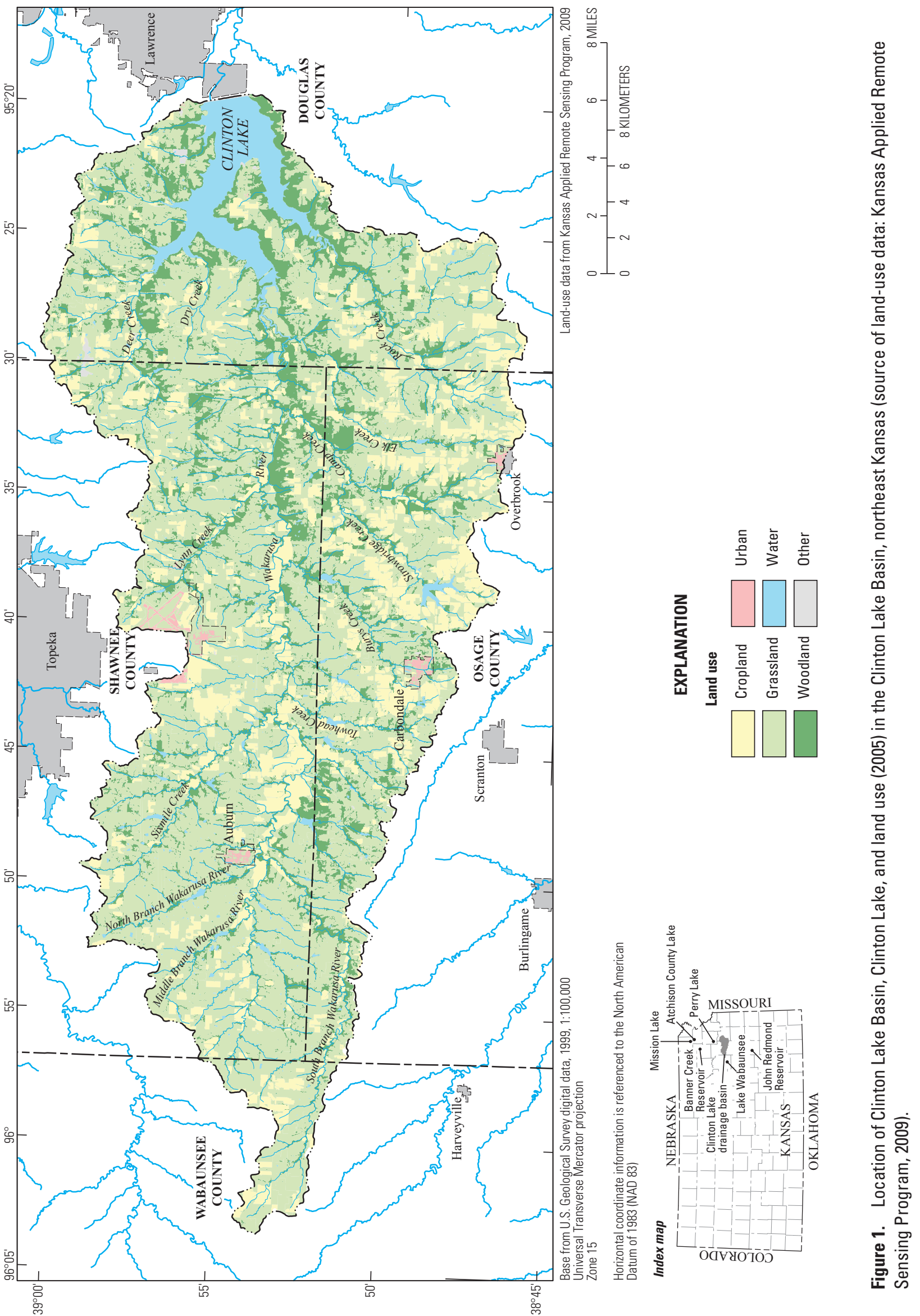
constituents and cyanobacterial akinetes in the bottom sediment of Clinton Lake for 1977 through 2009. Study objectives were accomplished by using available bathymetric information from USACE and KBS and by the collection and analysis of sediment cores in April and June 2009. Results presented in this report will assist KDHE in the evaluation, development, and implementation of TMDLs for constituents determined to contribute to water-quality impairment in the reservoir. From a national perspective, the methods and results presented provide guidance and perspective for future reservoir studies concerned with the issues of sedimentation and water quality.

\section{Description of Clinton Lake Basin}

The Clinton Lake Basin is an area of about $367 \mathrm{mi}^{2}$ (square miles) located in northeast Kansas (fig. 1). The majority of the Clinton Lake Basin is located in the Dissected Till Plains section of the Central Lowland physiographic province (Fenneman, 1946; Schoewe, 1949). This section is characterized by dissected deposits of glacial till that consist of clay, silt, sand, gravel, and boulders. The underlying bedrock is primarily limestone and shale (with some sandstone) of Pennsylvanian age (Schoewe, 1949; Jordan and Stamer, 1995). Soils in the basin mostly are clay loam, silt loam, and silty clay loam. Slopes in the basin range from nearly level to gently sloping on the flood plains and from gently sloping to steep in the uplands. Generally, slopes are less than 10 percent but locally may be as steep as 25 percent (U.S. Department of Agriculture, Soil Conservation Service, 1970, 1977, 1985, 1991). In addition to the Wakarusa River, several small tributaries contribute flow directly to Clinton Lake (fig. 1).

Long-term mean annual precipitation at Auburn, located in the upstream part of the Clinton Lake Basin (fig. 1), is about 36 in. (inches) (period of record 1960-2009) (High Plains Regional Climate Center, 2010). Most of the annual precipitation is received during the growing season (generally April-September).

Land use (2005) in the Clinton Lake Basin is mostly agricultural with grassland and cropland accounting for about 59 and 17 percent of the basin, respectively. Woodland accounts for about 18 percent of the basin. Urban land use occupies about 1 percent of the basin (fig. 1) (Kansas Applied Remote Sensing Program, 2009).

\section{Methods}

The objectives of this study were accomplished using available and newly collected information. Available information included original and updated reservoir water-storage capacity data from USACE and KBS bathymetric surveys and historical water-quality data from KDHE. New information was obtained through the analysis of bottom-sediment cores collected at eight sites in the reservoir.

\section{Estimation of Bottom-Sediment Volume, Mass, Mean Annual Net Deposition, and Mean Annual Net Yield}

The bottom-sediment volume (sediment plus pore water and gases) in the conservation pool of Clinton Lake was estimated by subtracting the updated water-storage capacity from the original water-storage capacity for the reservoir. The original water-storage capacity was estimated by USACE in 1977 to be 129,171 acre-ft (U.S. Army Corps of Engineers, 1979). An updated water-storage capacity was estimated by KBS in 2009 to be 119,106 acre-ft. Bottom-sediment volume was estimated as the 1977 water-storage capacity minus the 2009 water-storage capacity. The mean annual volume of sediment deposited (1977-2009) was computed as the bottomsediment volume divided by the number of years of deposition (32 years).

Bottom-sediment mass was estimated by multiplying the current (2009) bottom-sediment volume by the representative bulk density. The representative bulk density for the reservoir was computed as the average of the mean bulk densities that were determined from sediment cores (see discussion in "Physical Analyses" section later in this report). Because bulk density varies with location and the representative bulk density only accounts for eight sites in the reservoir, the estimated bottom-sediment mass has a potential error of unknown magnitude.

The mean annual mass of sediment (dry weight) deposited was estimated as the bottom-sediment mass divided by the age of the reservoir. Mean annual sediment yield from the reservoir basin was estimated by dividing the mean annual mass of deposited sediment by the area of the basin. Because sediment losses are not accounted for (for example, as a result of reservoir outflow), the estimated mean annual sediment deposition and yield represent net, rather than total, values. However, given that sediment trap efficiencies for large reservoirs typically are greater than 90 percent (Brune, 1953; Williams and Wolman, 1984; Shotbolt and others, 2005; Vanoni, 2006), sediment losses through the outflow likely are minimal. In a recent study, Lee and others (2008) estimated the trap efficiency for nearby John Redmond Reservoir (fig. 1) from February 21, 2007 to February 21, 2008 to be 91 percent.

\section{Sediment-Core Collection and Processing}

Bottom-sediment cores were collected in April and June of 2009 at eight sites (fig. 2) within Clinton Lake. The coring sites were selected to provide representative information throughout the reservoir and to provide an indication of spatial variability. All cores were collected from the submerged channels of the Wakarusa River and Rock Creek. Two cores were collected at sites CLK-1, CLK-4, and CLK-6 to provide sufficient sediment mass for physical, chemical, and cyanobacteria analyses. Of the eight sites cored, three were used for chemical analyses (CLK-1, CLK-4, and CLK-6), one was used 


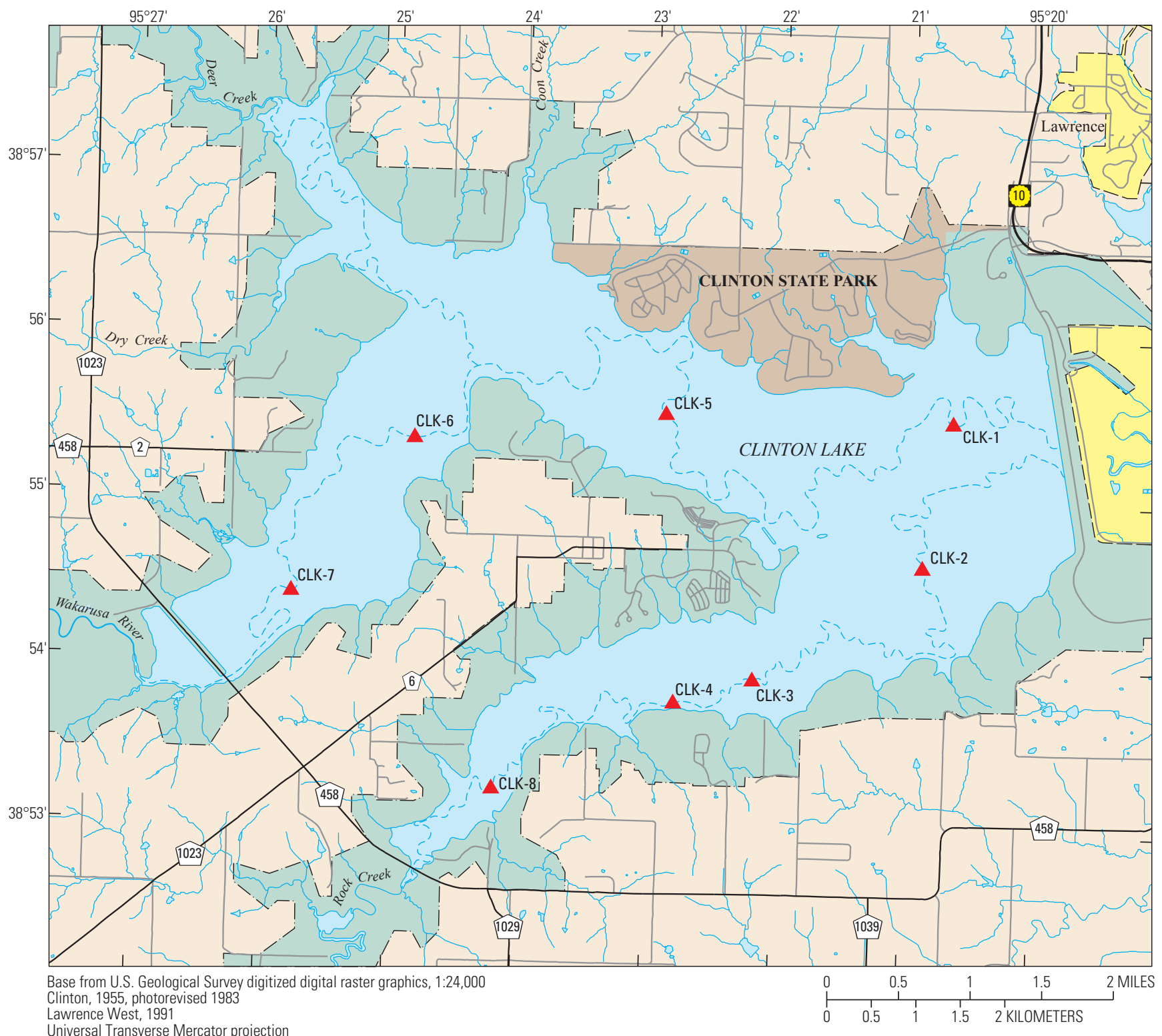

Universal Transverse Mercator projection

Zone 15

Horizontal coordinate information is referenced to the North American Datum of 1983 (NAD 83)

\section{EXPLANATION}

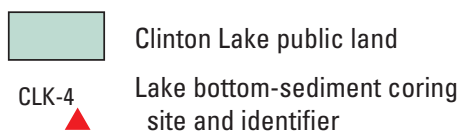

Figure 2. Location of bottom-sediment coring sites in Clinton Lake, northeast Kansas.

for cyanobacteria analyses (CLK-1), and all eight were used for bulk-density determinations (fig. 2).

The cores were collected from a pontoon boat using a gravity corer. The liner used for all cores was cellulose acetate butyrate transparent tubing with a 2.625 -in. inside diameter. The latitude and longitude for each coring site, obtained using GPS technology, are provided in table A1 in the "Supplemental Information" section at the back of this report.
When using a gravity corer, a phenomenon referred to as "core shortening" may occur that results in a recovered sediment core the length of which is less than the actual thickness of sediment penetrated (Emery and Hulsemann, 1964). Core shortening is caused by friction of the sediment against the inner wall of the core liner as the corer penetrates the sediment (Emery and Hulsemann, 1964; Hongve and Erlandsen, 1979; Blomqvist, 1985; Blomqvist and Bostrom, 1987). In "normal" 
lake-bottom sediment, which is characterized by uniform texture with decreasing water content at depth, core shortening results in a core that provides a thinned but complete representation of all of the sediment layers that were penetrated (Emery and Hulsemann, 1964; Hongve and Erlandsen, 1979). In this study, a comparison of the length of core recovered by gravity coring to the thickness of sediment penetrated indicated that core recovery ranged from 66 to 78 percent with an average of 72 percent. The thickness of sediment penetrated was computed as the total depth of corer penetration (as measured from the water surface) minus the water depth. Estimated penetration depth, length of core recovered, and estimated recovery percentage for the coring sites are provided in table $\mathrm{A} 1$ at the back of this report.

Because of the substantial thickness of the bottom sediment at the locations cored in Clinton Lake, penetration of the entire sediment thickness was not achieved for all cores. Complete penetration through the bottom sediment (evidenced by penetration into the underlying pre-reservoir land-surface material) was achieved for the cores used for chemical and cyanobacteria analyses at sites CLK-1, CLK-4, and CLK-6. Complete penetration also was achieved for the cores used for bulk-density determinations at sites CLK-2, CLK-4, and CLK-6. Complete penetration was not achieved for the cores used for bulk-density determinations at sites CLK-1, CLK3, CLK-5, CLK-7, and CLK-8. For these five cores, it was assumed that the sediment recovered provided representative bulk-density information for the entire sediment thickness at each site.

The sediment cores were transported to the USGS laboratory in Lawrence, Kansas, where they were stored vertically and refrigerated (at $4-5^{\circ} \mathrm{C}$ ) until processed. The core liners were cut lengthwise in two places 180 degrees apart. The cuts were completed with a 4-in. hand-held circular saw with the blade set at a depth to minimize penetration of the sediment cores. The cores were split in half by pulling a tightly held nylon string through the length of the cores and allowing the halves to separate. Once split, the relatively undisturbed inner parts of the cores were exposed for examination and sampling. On the basis of differences in moisture content, texture, and organic matter content (for example, root hairs, sticks, seed pods, and leaves), the boundary between the sediment deposited in the reservoir and the underlying pre-reservoir land-surface material was determined. Typically, the bottom sediment was characterized by higher moisture content, finer texture, and little if any visible organic matter as compared to the pre-reservoir material.

\section{Physical Analyses}

Physical analyses included bulk-density determinations and particle-size analyses. Bulk-density determinations were completed for a core from all eight coring sites. For this purpose, each core was divided into intervals of about one foot in length. The number of intervals was dependent on the length of each core. From each interval, a 1-in. thick cylindrical volume of sediment was removed using a putty knife, weighed to the nearest 0.10 gram, oven dried at about $40{ }^{\circ} \mathrm{C}$ for 96 hours, and reweighed. Oven drying of the sample continued as it was reweighed on a daily basis until no additional moisture loss was observed. Bulk density was computed as follows:

$$
D_{b}=m / v,
$$

where $D_{b}$ is the bulk density (in grams per cubic centimeter), $m$ is the mass (dry weight) of the sample (in grams), and $v$ is the volume of the sample (in cubic centimeters). The volume for a cylindrical sample was computed as:

$$
v=h\left(\pi d^{2} / 4\right),
$$

where $v$ is the volume of the sample (in cubic centimeters), $h$ is the height (length) of the sample (in centimeters), and $d$ is the diameter of the sample (in centimeters) (Gordon and others, 1992). The bulk densities were converted to pounds per cubic foot for use in subsequent computations. In all, 55 bulkdensity determinations were completed at the USGS laboratory in Lawrence, Kansas (table A2 at the back of this report).

Results for all sampled intervals were averaged to determine the mean bulk density for each core. The representative bulk density for bottom sediment in the reservoir was computed as the average of the mean bulk densities determined for the eight individual cores.

Particle-size analysis was performed to determine the percentage of sand (that is, particles larger than $0.063 \mathrm{~mm}$ (millimeters) in diameter) and silt and (or) clay (that is, particles smaller than $0.063 \mathrm{~mm}$ in diameter) in the sediment cores. Particle-size analyses were completed for a 10-interval core from coring sites CLK-1, CLK-4, and CLK-6. The sediment samples used for particle-size analyses also were used for constituent analyses (that is, nutrients, carbon, and trace elements). The particle-size analyses were completed at the USGS Sediment Trace Element Partitioning Laboratory in Atlanta, Georgia, according to the methods presented in Guy (1969).

\section{Chemical Analyses, Quality Control, and Age Dating}

A core collected from coring sites CLK-1, CLK-4, and CLK-6 was used for chemical analyses and age dating. In all cases, care was taken to avoid sampling sediment that came into contact with the core liner and saw blade. Each core was divided into 10 intervals of equal length. An approximately equal volume of sediment (defined as the space occupied by the sediment particles, water, and gases as measured in cubic units) was removed lengthwise from both halves of each interval and combined. The combined sediment volume for each interval was homogenized and then sampled for subsequent chemical analyses. 
Table 1. Chemical analyses for bottom-sediment samples from Clinton Lake, northeast Kansas, 2009.

[Number in parentheses is the method reporting limit for each constituent. $\mathrm{mg} / \mathrm{kg}$, milligrams per kilogram; \%, percent dry weight; dpm/g, disintegrations per minute per gram]

\begin{tabular}{|c|c|c|c|}
\hline \multicolumn{4}{|c|}{ Nutrients } \\
\hline Total nitrogen $(100 \mathrm{mg} / \mathrm{kg})$ & \multicolumn{3}{|l|}{ Total phosphorus (50 mg/kg) } \\
\hline \multicolumn{4}{|c|}{ Carbon } \\
\hline Carbon, total organic $(0.1 \%)$ & Carbon, total $(0.1 \%)$ & & \\
\hline \multicolumn{4}{|c|}{ Trace elements } \\
\hline Aluminum $(0.1 \%)$ & Cobalt $(1.0 \mathrm{mg} / \mathrm{kg})$ & Nickel $(1.0 \mathrm{mg} / \mathrm{kg})$ & Titanium $(0.01 \%)$ \\
\hline Antimony $(0.1 \mathrm{mg} / \mathrm{kg})$ & Copper $(1.0 \mathrm{mg} / \mathrm{kg})$ & Selenium (0.1mg/kg) & Uranium (50 mg/kg) \\
\hline Arsenic $(0.1 \mathrm{mg} / \mathrm{kg})$ & Iron $(0.1 \%)$ & Silver $(0.5 \mathrm{mg} / \mathrm{kg})$ & Vanadium $(1.0 \mathrm{mg} / \mathrm{kg})$ \\
\hline Barium (1.0 mg/kg) & Lead $(1.0 \mathrm{mg} / \mathrm{kg})$ & Strontium $(1.0 \mathrm{mg} / \mathrm{kg})$ & Zinc $(1.0 \mathrm{mg} / \mathrm{kg})$ \\
\hline Beryllium (0.1 mg/kg) & Lithium $(1.0 \mathrm{mg} / \mathrm{kg})$ & Sulfur $(0.01 \%)$ & \\
\hline Cadmium $(0.1 \mathrm{mg} / \mathrm{kg})$ & Manganese $(10.0 \mathrm{mg} / \mathrm{kg})$ & Thallium $(50 \mathrm{mg} / \mathrm{kg})$ & \\
\hline Chromium $(1.0 \mathrm{mg} / \mathrm{kg})$ & Molybdenum $(1.0 \mathrm{mg} / \mathrm{kg})$ & $\operatorname{Tin}(1.0 \mathrm{mg} / \mathrm{kg})$ & \\
\hline \multicolumn{4}{|c|}{ Radionuclide } \\
\hline Cesium-137 (0.05 dpm/g) & & & \\
\hline
\end{tabular}

Each of the 10-interval cores was analyzed for nutrients (total nitrogen and total phosphorus), organic and total carbon, and 25 trace elements. A complete list of the analyzed constituents is provided in table 1. Constituent analyses of bottomsediment samples were performed at the USGS Sediment Trace Element Partitioning Laboratory in Atlanta, Georgia. Analyses of sediment samples for total nitrogen and carbon concentrations were performed using the methods described by Horowitz and others (2001). Analyses for total phosphorus and trace elements were performed using the methods described by Fishman and Friedman (1989), Arbogast (1996), and Briggs and Meier (1999).

Quality control for the chemical analyses of sediment samples was provided by an evaluation of variability that involved an analysis of split-replicate samples collected from coring sites CLK-1, CLK-4, and CLK-6. The split-replicate samples were obtained by removing a representative volume of sediment from each selected core interval, homogenizing it, and sampling it twice. Three split-replicate samples were analyzed for nutrients, carbon, and trace elements. The relative percentage difference between the replicate sample concentrations was computed as the absolute value of the difference in the replicate analyses divided by the mean and expressed as a percentage.

Analytical variability was minimal with mean relative percentage differences less than 5 percent. The relative percentage differences computed for the constituents detected in the split-replicate samples are provided in table 2 .

Age dating of the bottom sediment was accomplished by determining the activity of cesium- $137\left({ }^{137} \mathrm{Cs}\right) \cdot{ }^{137} \mathrm{Cs}$ is a radioactive isotope that is a by-product of above-ground nuclear weapons testing. Measurable activity of this isotope first appeared in the atmosphere about 1952, peaked during 1963-64, and has since declined (Ritchie and McHenry,
1990). Measurable activity in soils began about 1954 (Wise, 1980). ${ }^{137} \mathrm{Cs}$ is an effective marker for age dating bottom sediment in reservoirs constructed before 1963-64 (Van Metre and others, 1997). It also can be used to demonstrate that the sediment is relatively undisturbed if the 1963-64 peak is welldefined and a generally uniform, exponential decrease in ${ }^{137} \mathrm{Cs}$ activity follows the peak. Age dating of sediment using ${ }^{137} \mathrm{Cs}$ was attempted for Clinton Lake coring sites CLK-1, CLK-4, and CLK-6 (fig. 2). Because Clinton Lake was completed in 1977 (that is, after the ${ }^{137} \mathrm{Cs}$ peak), it was anticipated that the use of ${ }^{137} \mathrm{Cs}$ in this study would be limited to an assessment of postdepositional disturbance. Analysis of sediment samples for ${ }^{137} \mathrm{Cs}$ activity was performed at the USGS Florida Integrated Science Center in St. Petersburg, Florida, using gamma-ray spectrometry (Holmes and others, 2001).

Given that Clinton Lake was completed after the ${ }^{137} \mathrm{Cs}$ peak, the anticipated profile of ${ }^{137} \mathrm{Cs}$ activity for a minimally disturbed site was one with a peak in ${ }^{137} \mathrm{Cs}$ activity at the bottom of the core followed by a uniform, exponential decrease in activity to the top of the core. The anticipated profile was observed for the upper (most recently deposited) two-thirds of the core for coring site CLK-1 (fig. $3 A$ ). Lower ${ }^{137} \mathrm{Cs}$ activity at the bottom of the core may be caused, in part, by analytical variability. However, the lower ${ }^{137} \mathrm{Cs}$ activity also may be indicative of a change in sediment source. Typically, subsurface material, including channel banks, have substantially lower ${ }^{137} \mathrm{Cs}$ activity compared to surface soils (He and Owens, 1995; Walling and Woodard, 1995; Juracek and Ziegler, 2009). Thus, a possible explanation for the lower ${ }^{137} \mathrm{Cs}$ activity at the bottom of the core is that the contribution of sediment from subsurface material was relatively greater during the early history of the reservoir. The increased contribution of sediment from subsurface sources may have originated within the reservoir (for example, from localized channel bank and 
Table 2. Relative percentage differences for constituent concentrations in splitreplicate samples from bottom sediment cores from Clinton Lake, northeast Kansas.

[Location of coring sites shown in figure 2. --, not calculated because constituent was not detected in one or more of the split-replicate samples]

\begin{tabular}{|c|c|c|c|c|}
\hline \multirow[b]{2}{*}{ Constituent } & \multicolumn{4}{|c|}{ Relative percentage difference } \\
\hline & $\begin{array}{c}\text { Coring site } \\
\text { CLK-1 }\end{array}$ & $\begin{array}{c}\text { Coring site } \\
\text { CLK-4 }\end{array}$ & $\begin{array}{l}\text { Coring site } \\
\text { CLK-6 }\end{array}$ & Mean \\
\hline \multicolumn{5}{|c|}{ Nutrients } \\
\hline Total nitrogen & 0 & 0 & 0 & 0 \\
\hline Total phosphorus & 0 & 1.2 & 3.0 & 1.4 \\
\hline \multicolumn{5}{|c|}{ Carbon } \\
\hline Carbon, total organic & 0 & 0 & 0 & 0 \\
\hline Carbon, total & 0 & 9.5 & 4.7 & 4.7 \\
\hline \multicolumn{5}{|c|}{ Trace elements } \\
\hline Aluminum & 1.1 & 2.4 & 2.2 & 1.9 \\
\hline Antimony & 8.7 & 0 & 0 & 2.9 \\
\hline Arsenic & 0 & 0 & 0 & 0 \\
\hline Barium & 1.6 & 1.6 & 1.5 & 1.6 \\
\hline Beryllium & 0 & 0 & 3.6 & 1.2 \\
\hline Cadmium & 0 & 0 & 0 & 0 \\
\hline Chromium & 1.0 & 2.3 & 0 & 1.1 \\
\hline Cobalt & 0 & 0 & 0 & 0 \\
\hline Copper & 3.4 & 0 & 3.4 & 2.3 \\
\hline Iron & 0 & 2.4 & 2.2 & 1.5 \\
\hline Lead & 3.8 & 0 & 3.6 & 2.5 \\
\hline Lithium & 3.2 & 1.9 & 1.8 & 2.3 \\
\hline Manganese & 0 & 0 & 1.0 & .3 \\
\hline Molybdenum & 0 & -- & -- & -- \\
\hline Nickel & 4.5 & 2.6 & 2.5 & 3.2 \\
\hline Selenium & 0 & 0 & 11.8 & 3.9 \\
\hline Silver & -- & -- & -- & -- \\
\hline Strontium & 0 & 0 & 0 & 0 \\
\hline Sulfur & 0 & 0 & 0 & 0 \\
\hline Thallium & -- & -- & -- & -- \\
\hline Tin & 0 & 0 & 0 & 0 \\
\hline Titanium & 2.4 & 2.2 & 0 & 1.5 \\
\hline Uranium & -- & -- & -- & -- \\
\hline Vanadium & 0 & 7.4 & 0 & 2.5 \\
\hline Zinc & 0 & 0 & 0 & 0 \\
\hline
\end{tabular}

shoreline erosion). For coring site CLK-4, a profile of generally decreasing ${ }^{137} \mathrm{Cs}$ activity to the top of the core was measured (fig. 3B). With the exception of the bottom core interval for which anomalously low ${ }^{137} \mathrm{Cs}$ activity was measured, a profile of decreasing ${ }^{137} \mathrm{Cs}$ activity to the top of the core was measured for coring site CLK-6 (fig. 3C). As at coring site
CLK-1, the anomalously low ${ }^{137} \mathrm{Cs}$ activity at the bottom of the CLK-6 core may be indicative of an increased contribution of sediment from local subsurface sources during the early history of the reservoir. Additional evidence in support of a change in sediment source at the bottom of the CLK-1 and CLK-6 cores was provided by the particle-size composition 

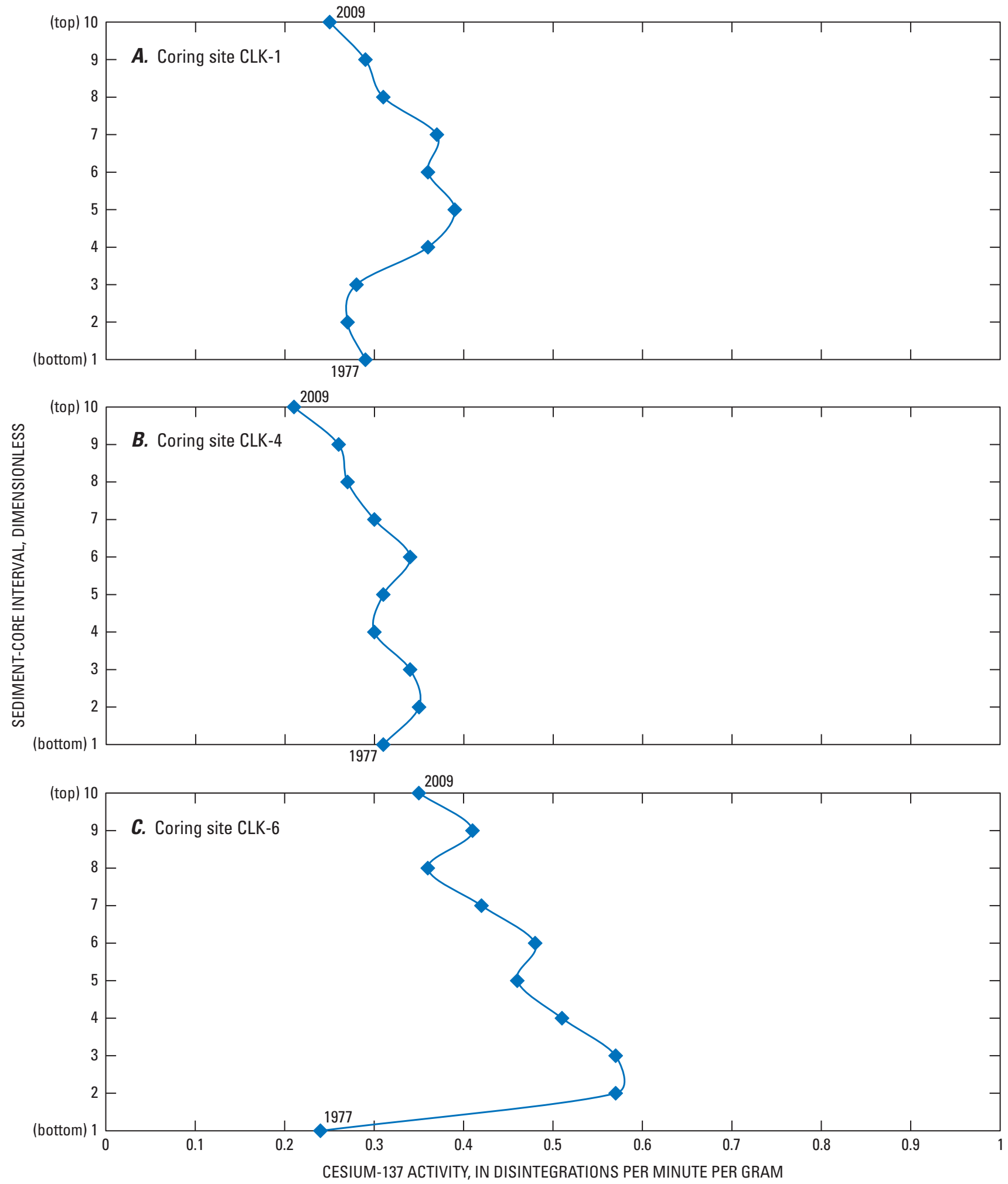

Figure 3. Variation in cesium-137 activity with depth of bottom-sediment samples collected from coring sites $(A)$ CLK-1, $(B)$ CLK4, and (C) CLK-6 in Clinton Lake, northeast Kansas, April 2009. 
of the sediment. At the bottom of both cores, a consistently lower percentage of silt and clay was measured (tables A3 and A5 at the back of this report). The lower percentage of silt and clay may be indicative of a local sediment source (that is, less time for coarser particles to settle out prior to deposition). If the proposed interpretation of the ${ }^{137} \mathrm{Cs}$ profiles is correct, then the bottom sediment at these coring sites may be relatively undisturbed. Thus, any trends in constituent deposition at the three coring sites may be considered meaningful.

\section{Estimation of Nutrient Loads and Yields}

The mean annual load and yield of total nitrogen (TN) and total phosphorus (TP) was estimated for Clinton Lake for the period 1977 to 2009. For each nutrient, mean annual load was estimated as the representative sediment concentration multiplied by the mean annual mass of sediment deposited in the reservoir. The representative sediment concentration was computed as the median of the sample intervals analyzed for cores CLK-1, CLK-4, and CLK-6.

The mean annual yield for each nutrient was estimated by dividing the mean annual load by the area of the Clinton Lake Basin. Because sediment losses are not accounted for (for example, as a result of reservoir outflow), the computed loads and yields represent net, rather than total, values.

\section{Trend Analysis}

Temporal trends in nutrient, carbon, and trace-element concentrations (in relation to depth in the sediment profile) were examined for coring sites CLK-1, CLK-4, and CLK-6 by computing a nonparametric Spearman's rho correlation coefficient. An advantage of Spearman's rho is that, because it is based on ranks, it is more resistant to outlier effects than the more commonly used Pearson's $r$ correlation coefficient (Helsel and Hirsch, 1992). Measures of correlation are dimensionless and scaled to be in the range of -1.0 to 1.0. A value of 0 indicates no relation between two variables. Temporal trends were considered to be significantly positive (with a value between 0 and 1.0 indicating that the constituent concentration increased toward the top of the sediment core) or negative (with a value between 0 and -1.0 indicating that the constituent concentration decreased toward the top of the sediment core) if the probability (two-sided p-value) of rejecting a correct hypothesis (in this case, no trend) was less than or equal to 0.05 . A possible trend was only considered meaningful if the change in constituent concentration was beyond the variability that could be explained by analytical variance (defined here as the mean constituent concentration in the sediment core plus or minus 10 percent). The possibility must be recognized that constituent concentrations in the cores may have been affected by diagenesis (that is, postdepositional changes caused by processes such as remobilization and diffusion).

For each coring site, the core intervals included in the trend analyses were selected based on the ${ }^{137} \mathrm{Cs}$ and particle-size results. Only the top (most recently deposited) seven intervals were used for the core collected at site CLK-1. The bottom three intervals were excluded from trend analysis because anomalously low ${ }^{137} \mathrm{Cs}$ activity and a lower percentage of silt and clay indicated that these intervals may consist partly or mostly of locally derived sediment (that is, originating within the reservoir), which may be chemically different from and not representative of sediment originating from the upstream basin. Likewise, for the core collected at site CLK-6, the bottom interval was excluded from the trend analyses. All 10 intervals were included for the core collected at site CLK-4.

\section{Cyanobacteria Analysis}

Cyanobacteria (also called blue-green algae) are indicative of eutrophic conditions in lakes and reservoirs (Wetzel, 2001). To investigate the occurrence of eutrophic conditions throughout the history of Clinton Lake, the core collected at site CLK-1 was analyzed for cyanobacterial akinetes using the same 10 intervals that were analyzed for chemical constituents. Akinetes are thick-walled, resistant cells that represent the resting stage of cyanobacteria (Adams and Duggan, 1999; Wetzel, 2001). They provide an approximate estimate of past cyanobacterial abundance (Rasanen and others, 2006) and can be used to investigate the trophic history of a lake (van Geel and others, 1994; Kling, 1998). Akinetes preserve well in sediment as evidenced by past studies that documented preservation for periods ranging from decades (Livingstone and Jaworski, 1980; Kling, 1998; Rasanen and others, 2006) to centuries (Cronberg, 1986; van Geel and others, 1994). Analysis of the sediment samples for akinetes was performed by PhycoTech, Inc., St. Joseph, Michigan.

\section{Sediment-Quality Guidelines}

The U.S. Environmental Protection Agency (USEPA) has adopted nonenforceable sediment-quality guidelines (SQGs) in the form of level-of-concern concentrations for several trace elements (U.S. Environmental Protection Agency, 1997). These level-of-concern concentrations were derived from biological-effects correlations made on the basis of paired onsite and laboratory data to relate incidence of adverse biological effects in aquatic organisms to dry-weight sediment concentrations. Two such level-of-concern guidelines adopted by USEPA are referred to as the threshold-effects level (TEL) and the probable-effects level (PEL). The TEL is assumed to represent the concentration below which toxic biological effects rarely occur. In the range of concentrations between the TEL and PEL, toxic effects occasionally occur. Toxic effects usually or frequently occur at concentrations above the PEL.

USEPA cautions that the TEL and PEL guidelines are intended for use as screening tools for possible hazardous levels of chemicals and are not regulatory criteria. This 
cautionary statement is made because, although biologicaleffects correlation identifies level-of-concern concentrations associated with the likelihood of adverse organism response, the comparison may not demonstrate that a particular chemical is solely responsible. In fact, biological-effects correlations may not indicate direct cause-and-effect relations because sediments may contain a mixture of chemicals that contribute to the adverse effects to some degree. Thus, for any given site, these guidelines may be over- or underprotective (U.S. Environmental Protection Agency, 1997).

MacDonald and others (2000) developed consensusbased SQGs for several trace elements that were computed as the geometric mean of several previously published SQGs. The consensus-based SQGs consist of a threshold-effect concentration (TEC) and a probable-effect concentration (PEC). The TEC represents the concentration below which adverse effects are not expected to occur, whereas the PEC represents the concentration above which adverse effects are expected to occur more often than not. An evaluation of the reliability of the SQGs indicated that most of the individual TECs and PECs provide an accurate basis for predicting the presence or absence of sediment toxicity (MacDonald and others, 2000).

A comparison of the two sets of trace-element SQGs indicated some differences (table 3). The largest difference was for the zinc PEL and PEC. In this case, the PEC (459 mg/kg (milligrams per kilogram)) was about 69 percent larger than the PEL (271 mg/kg). For this study, the SQGs used were selected to provide a less-stringent assessment. Thus, for each trace element for which SQGs were available, the larger of the two options for threshold effects and probable effects was selected for the purpose of assessing sediment quality (see shaded values in table 3). The options used to assess sediment quality are

Table 3. Sediment-quality guidelines for selected trace elements and associated bioaccumulation index.

[Values in milligrams per kilogram. Shading represents guidelines to which sediment concentrations were compared in this report. USEPA, U.S. Environmental Protection Agency; TEL, threshold-effects level; PEL, probableeffects level; TEC, threshold-effect concentration; PEC, probable-effect concentration; --, not available]

\begin{tabular}{|c|c|c|c|c|c|}
\hline \multirow{2}{*}{$\begin{array}{l}\text { Trace } \\
\text { element }\end{array}$} & \multicolumn{2}{|c|}{ USEPA (1997) } & \multicolumn{2}{|c|}{$\begin{array}{c}\text { MacDonald and } \\
\text { others }(2000)\end{array}$} & \multirow{2}{*}{$\begin{array}{c}\text { Bioaccu } \\
\text { mulation } \\
\text { index }^{1}\end{array}$} \\
\hline & TEL & PEL & TEC & PEC & \\
\hline Arsenic & 7.24 & 41.6 & 9.79 & 33.0 & moderate \\
\hline Cadmium & .676 & 4.21 & .99 & 4.98 & moderate \\
\hline Chromium & 52.3 & 160 & 43.4 & 111 & moderate \\
\hline Copper & 18.7 & 108 & 31.6 & 149 & high \\
\hline Lead & 30.2 & 112 & 35.8 & 128 & moderate \\
\hline Nickel & 15.9 & 42.8 & 22.7 & 48.6 & moderate \\
\hline Silver & .733 & 1.77 & -- & -- & moderate \\
\hline Zinc & 124 & 271 & 121 & 459 & high \\
\hline
\end{tabular}

${ }^{1}$ Bioaccumulation index information for trace elements from Pais and Jones (1997). hereafter referred to as the threshold-effects guidelines, which represent the concentrations above which toxic biological effects occasionally occur, and the probable-effects guidelines, which represent the concentrations above which toxic biological effects usually or frequently occur.

\section{Background Information for Selected Chemical Constituents and Cyanobacteria}

\section{Nutrients and Total Organic Carbon}

Nutrients, such as nitrogen and phosphorus, are necessary for growth and reproduction of plants. In most freshwater environments, phosphorus is one of the principal limiting factors for primary production (Hakanson and Jansson, 1983; Wetzel, 2001). If phosphorus concentrations are too large, algal growth may become excessive and possibly result in the production of algal toxins and taste-and-odor compounds. Additionally, excessive algal growth may be detrimental to aquatic life and limit recreational use of a lake. Even small increases in phosphorus can cause increases in algal biomass provided that light limitation is not an issue (Dillon and Rigler, 1974; Jones and Bachmann, 1976; Jones and others, 2008). Major human-related sources of nutrients include fertilizer application, livestock production, and sewage-treatment plants.

Total organic carbon (TOC), an approximate determination of total organic material in a sediment sample, is important because various organic solutes can form complexes, which in turn affect trace-element solubilities (Hem, 1989). The organic carbon content of sediment also is important because many contaminants specifically sorb to the organic material in sediment (Karickhoff, 1984; Horowitz, 1991).

\section{Trace Elements}

Trace elements are important determinants of sediment quality because of their potential toxicity to living organisms (Forstner and Wittmann, 1981; Smol, 2002; Luoma and Rainbow, 2008). Trace elements may be defined as elements that typically are present in the environment in relatively low (less than 0.1 percent) concentrations (Pais and Jones, 1997; Adriano, 2001). Using this definition, the majority of the elements analyzed in this study may be considered trace elements. Exceptions, which are some of the abundant rock-forming elements, include aluminum and iron (Adriano, 2001).

Trace elements in sediment originate naturally from the rock and soil within a basin. Elevated concentrations of sediment-associated trace elements may be attributable to several human-related sources including fertilizers, liming materials, 
pesticides, irrigation water, animal and human wastes, coal combustion residues, leaching from landfills, mining, metalsmelting industries, and automobile emissions (Forstner and Wittmann, 1981; Davies, 1983; Adriano, 2001; Luoma and Rainbow, 2008).

The health of living organisms is dependent on a sufficient intake of various trace elements. Many elements, such as cobalt, copper, iron, manganese, and zinc, are essential for plants, animals, and humans. Other elements, such as arsenic and chromium, are required by animals and humans but are not essential for plants. Nonessential elements for plants, animals, and humans include cadmium, mercury, and lead (Lide, 1993; Pais and Jones, 1997; Adriano, 2001; Marmiroli and Maestri, 2008).

Toxicity is a function of several factors including the type of organism, availability of a trace element in the environment, and its potential to bioaccumulate once in the food chain. The daily intake of trace elements by animals and humans may be classified as deficient, optimal, or toxic. Most, if not all, trace elements may be toxic in animals and humans if the concentrations are sufficiently large (Pais and Jones, 1997; Smol, 2002; Luoma and Rainbow, 2008). Information on the bioaccumulation index (Pais and Jones, 1997) for trace elements with available SQGs is provided in table 3 . The bioaccumulation index indicates the relative potential of a trace element to bioaccumulate in organisms.

\section{Cyanobacteria}

Cyanobacteria are common in freshwater ecosystems (Chorus and Bartram, 1999; Wetzel, 2001) and often are associated with eutrophic conditions (Smol, 2002). A eutrophic lake is characterized by nutrient-rich water with high primary productivity (Horne and Goldman, 1994). Abundant growth of cyanobacteria is a concern because it can limit recreational use of a lake, cause taste-and-odor problems for water suppliers, and produce toxins (for example, microcystins) which are a concern for human health (Chorus and Bartram, 1999).

\section{Sedimentation}

Based on the difference between the 1977 USACE and 2009 KBS estimated water-storage capacities, the total volume of bottom sediment deposited in the conservation pool of Clinton Lake was estimated to be about 438 million $\mathrm{ft}^{3}$ (cubic feet) or about 10,065 acre-ft. The estimated sediment volume occupied about 8 percent of the conservation-pool, waterstorage capacity of the reservoir. Water-storage capacity in the conservation pool has been lost to sedimentation at a rate of about 0.25 percent annually.
As part of the original 100-year design life for Clinton Lake, USACE allocated 19,000 acre-ft for sediment storage in the conservation pool of the reservoir (U.S. Army Corps of Engineers, 1979). Restated, it was projected that after 100 years there would be 19,000 acre-ft of sediment deposited in the conservation pool. The original projected mean annual sedimentation rate was 190 acre-ft per year. Recently (2010), the Kansas Water Office estimated the mean annual sedimentation rate to be 324 acre-ft per year, which is about 70 percent larger than the original projection (Kansas Water Office, 2010). At this rate, the allocated 19,000 acre-ft for sediment storage would be filled in about 60 years.

Mean annual net sediment yield, computed as the total volume of deposited sediment (10,065 acre-ft) divided by basin size $\left(367 \mathrm{mi}^{2}\right)$ and reservoir age (32 years), was estimated to be 0.86 acre-ft $/ \mathrm{mi}^{2} / \mathrm{yr}$ (acre-feet per square mile per year). A comparison of the volumetric sediment yield with other selected reservoir basins in Kansas is provided in table 4. Among the large reservoirs compared, the sediment yield for Clinton Lake was relatively high. In an analysis performed in 2004 that included 11 reservoirs listed in table 4 (Clinton and Fall River Lakes excluded), a statistically significant positive correlation (significant at the 0.001 level) between sediment yield and mean annual precipitation (Spearman's rho $=0.86$ ) was indicated (Juracek, 2004). Thus, for the 11 reservoirs included in the analysis, mean annual precipitation was the best predictor of sediment yield. In the same analysis, no statistically significant correlation (at the 0.05 level) was indicated for the relation between sediment yield and mean soil permeability, mean slope, or land use. Within and between basins, sediment yield is spatially and temporally variable as a result of the complex interaction among several factors including topography, soil types, precipitation, vegetation, human disturbance, and sediment storage (Morris and Fan, 1998).

The total mass of bottom sediment in the conservation pool, computed as the total volume of bottom sediment multiplied by the representative bulk density of the sediment ( $41 \mathrm{lb} / \mathrm{ft}^{3}$ (pounds per cubic foot)), was estimated to be about 18 billion $\mathrm{lb}$. Mean annual net sediment deposition, computed as the total bottom-sediment mass divided by reservoir age, was estimated to be 563 million lb/yr. Mean annual net sediment yield, computed as the mean annual net deposition divided by basin area, was estimated to be 1.5 million $\left(\mathrm{lb} / \mathrm{mi}^{2}\right) / \mathrm{yr}$. In comparison, Juracek (2003) estimated the mean annual net sediment deposition and mean annual net sediment yield for nearby Perry Lake to be 3,040 million $\mathrm{lb} / \mathrm{yr}$ and 2.7 million $\left(\mathrm{lb} / \mathrm{mi}^{2}\right) / \mathrm{yr}$, respectively.

The particle-size composition of the bottom sediment sampled in Clinton Lake was uniform. For the 30 sediment samples analyzed, the percentage of silt and clay was equal to or greater than 94 percent and typically was equal to or greater than 99 percent (tables A3, A4, and A5 at the back of this report). 
Table 4. Sediment yield, precipitation, and land use for selected reservoir basins in Kansas.

[Reservoir basins are ordered from largest to smallest in sediment yield. Information for reservoirs other than Clinton Lake from Juracek, 2004, 2008. mi², square miles]

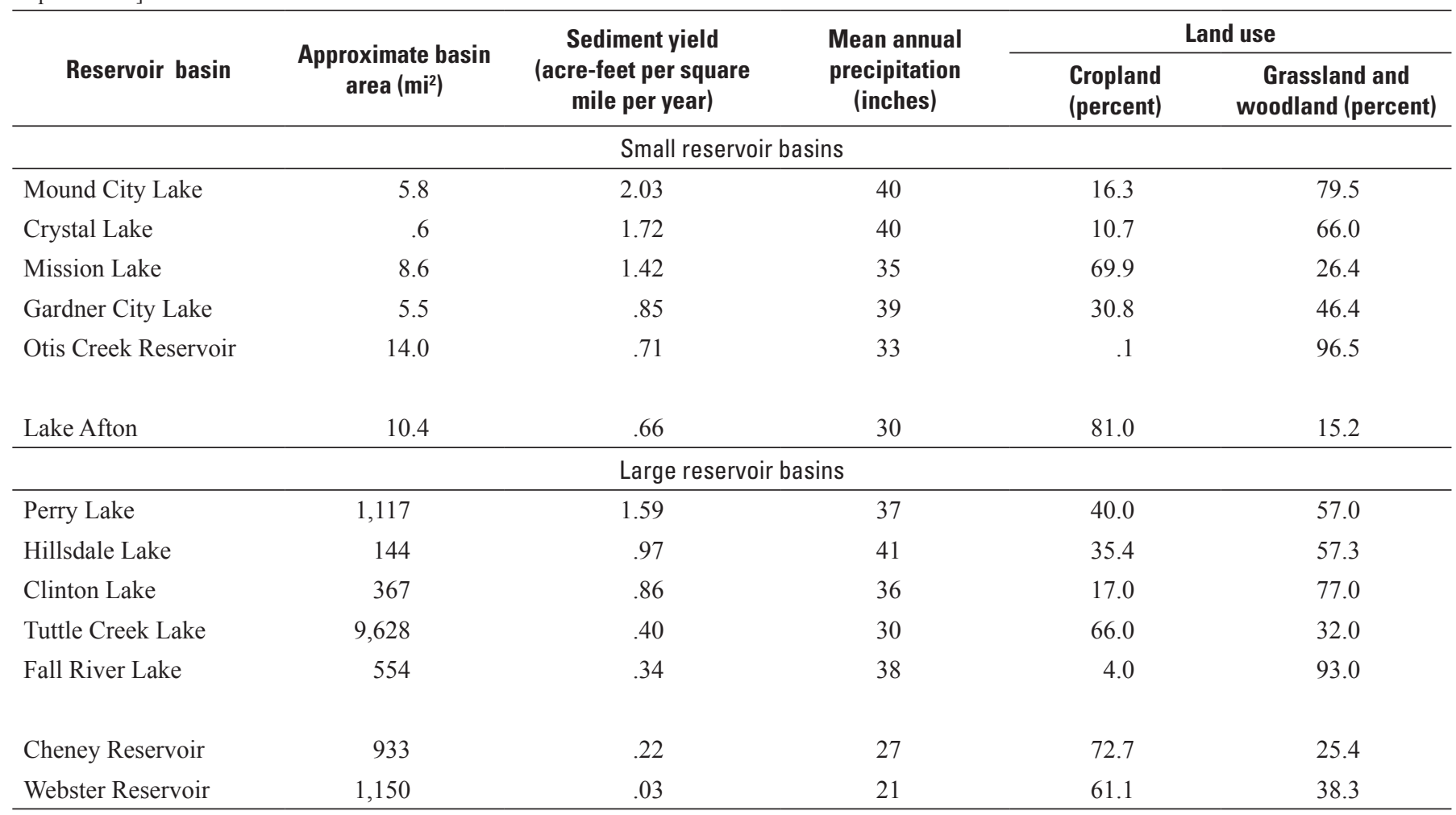

\section{Occurrence of, and Trends in, Selected Chemical Constituents and Cyanobacteria}

This section describes the occurrence of, and trends in, selected chemical constituents and cyanobacterial akinetes in bottom-sediment samples collected from Clinton Lake in northeast Kansas. Chemical analyses were performed using sediment samples from cores CLK-1, CLK-4, and CLK-6 (fig. 2). A total of 30 sediment samples were analyzed for nutrients, carbon, and trace elements. Only samples from core CLK-1 were analyzed for cyanobacterial akinetes. Sediment quality was assessed with reference to available SQGs for selected trace elements (table 3 ).

\section{Nutrients and Total Organic Carbon}

$\mathrm{TN}$ concentrations in the bottom sediment of Clinton Lake generally were uniform over time (fig. 4) if the bottom three intervals of the core collected at site CLK- 1 and the bottom interval of the core collected at site CLK-6 are excluded because they may not be representative of sediment originating from the upstream basin. The generally uniform TN concentrations in the sediment indicated consistent inputs to the reservoir over time. Excluding the bottom three intervals, TN concentrations in the CLK-1 core ranged from 2,500 to $2,900 \mathrm{mg} / \mathrm{kg}$ with a median of $2,700 \mathrm{mg} / \mathrm{kg}$ (table A3 at the back of this report). TN concentrations in the CLK-4 core ranged from 2,000 to $2,200 \mathrm{mg} / \mathrm{kg}$ with a median of $2,100 \mathrm{mg} / \mathrm{kg}$ (table A4 at the back of this report). Excluding the bottom interval, TN concentrations in the CLK-6 core ranged from 2,200 to $2,600 \mathrm{mg} / \mathrm{kg}$ with a median of $2,300 \mathrm{mg} / \mathrm{kg}$ (table A5 at the back of this report). Excluding the same four core intervals noted above, the overall median $\mathrm{TN}$ concentration in the bottom sediment of Clinton Lake was $2,300 \mathrm{mg} / \mathrm{kg}$. In comparison, the median TN concentration in the bottom sediment of nearby Perry Lake (fig. 1) was 2,500 mg/kg (Juracek, 2003).

The possible positive trend in $\mathrm{TN}$ concentrations for the top (most recently deposited) seven intervals of the CLK-1 core (fig. 4) was not statistically significant at the 0.05 level (table 5). The possible negative trend in TN concentrations for the top (most recently deposited) nine intervals of the CLK-6 core (fig. 4) was statistically significant (table 5). However, because most of the intervals had a TN concentration that was within 10 percent of the mean TN concentration for the core, the TN trend may not be representative of an actual trend because of analytical variability.

The mean annual net load of TN deposited in the bottom sediment of Clinton Lake, computed as the mean annual net sediment deposition multiplied by the representative TN concentration $(2,300 \mathrm{mg} / \mathrm{kg})$, was estimated to be 1.29 million 


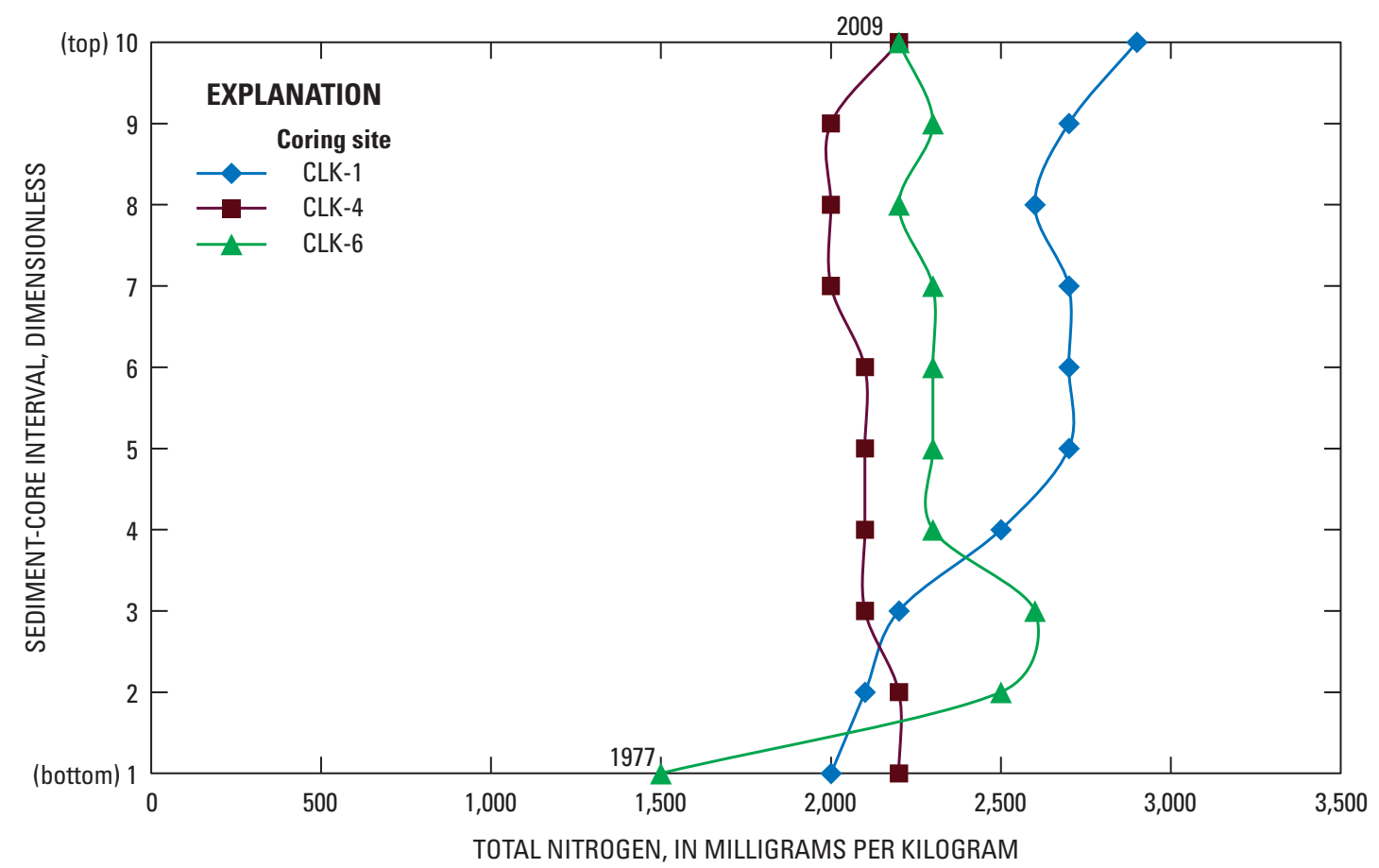

Figure 4. Variation in total nitrogen concentrations with depth of bottom-sediment samples collected from coring sites CLK-1, CLK-4, and CLK-6 in Clinton Lake, northeast Kansas, April 2009.

lb/yr. The mean annual net yield of TN from the Clinton Lake Basin, computed as the mean annual net load divided by basin area, was estimated to be $3,510\left(\mathrm{lb} / \mathrm{mi}^{2}\right) / \mathrm{yr}$.

$\mathrm{TP}$ concentrations in the bottom sediment of Clinton Lake generally were uniform over time (fig. 5) if the same four core intervals previously noted are excluded. Thus, as for $\mathrm{TN}$, the generally uniform TP concentrations in the sediment indicated consistent inputs to the reservoir over time. The TP depositional profiles parallel the $\mathrm{TN}$ depositional profiles (figs. 4 and 5). Excluding the bottom three intervals, TP concentrations in the CLK-1 core ranged from 980 to $1,200 \mathrm{mg} /$ $\mathrm{kg}$ with a median of $1,100 \mathrm{mg} / \mathrm{kg}$ (table A3). For the CLK-4 core, TP concentrations ranged from 840 to $910 \mathrm{mg} / \mathrm{kg}$ with a median of 865 (table A4). Excluding the bottom interval, TP concentrations in the CLK-6 core ranged from 960 to 1,000 $\mathrm{mg} / \mathrm{kg}$ with a median of $1,000 \mathrm{mg} / \mathrm{kg}$ (table A5). Excluding the same four core intervals noted above, the overall median TP concentration in the bottom sediment of Clinton Lake was $990 \mathrm{mg} / \mathrm{kg}$. In comparison, the median TP concentration in the bottom sediment of nearby Perry Lake (fig. 1) was 1,100 mg/ kg (Juracek, 2003).

The possible positive trend in TP concentrations for the top seven intervals of the CLK-1 core (fig. 5) was statistically significant at the 0.05 level (table 5). However, because most of the intervals had a TP concentration that was within 10 percent of the mean TP concentration for the core, the TP trend may not be representative of an actual trend because of analytical variability. A statistically significant positive trend in TP concentrations also was determined for the CLK-4 core (table 5). However, because all of the intervals had a TP concentration that was well within 10 percent of the mean TP concentration for the core, this trend also may not be real.

The mean annual net load of TP deposited in the bottom sediment of Clinton Lake, computed as the mean annual net sediment deposition multiplied by the representative TP concentration $(990 \mathrm{mg} / \mathrm{kg})$, was estimated to be $556,000 \mathrm{lb} / \mathrm{yr}$. The mean annual net yield of TP from the Clinton Lake Basin, computed as the mean annual net load divided by basin area, was estimated to be $1,510\left(\mathrm{lb} / \mathrm{mi}^{2}\right) / \mathrm{yr}$.

A comparison of the nutrient concentrations for the three coring sites indicated that the largest TN and TP concentrations were measured for the CLK-1 core, which was the downstream most core analyzed (fig. 2, tables A3-A5). The downstream increase in nutrient concentrations may be related, in part, to changes in the particle-size composition of the bottom sediment. Within a reservoir, particle size typically decreases with distance downstream as progressively smaller particles settle out (Morris and Fan, 1998). Thus, the percentage of clay in the bottom sediment would be expected to increase with distance downstream in a reservoir. Downstream increases in TN and TP concentrations in sediment, with accompanying increases in the percentage of clay in the sediment, were reported for Atchison County Lake, Banner Creek Reservoir, Lake Wabaunsee, Mission Lake, and Perry Lake in northeast Kansas (Juracek and Ziegler, 2007) (fig. 1).

Nutrient concentrations for the two upstream coring sites, CLK-4 (located in the Rock Creek arm of the reservoir) and CLK-6 (located in the Wakarusa River arm of the reservoir), 


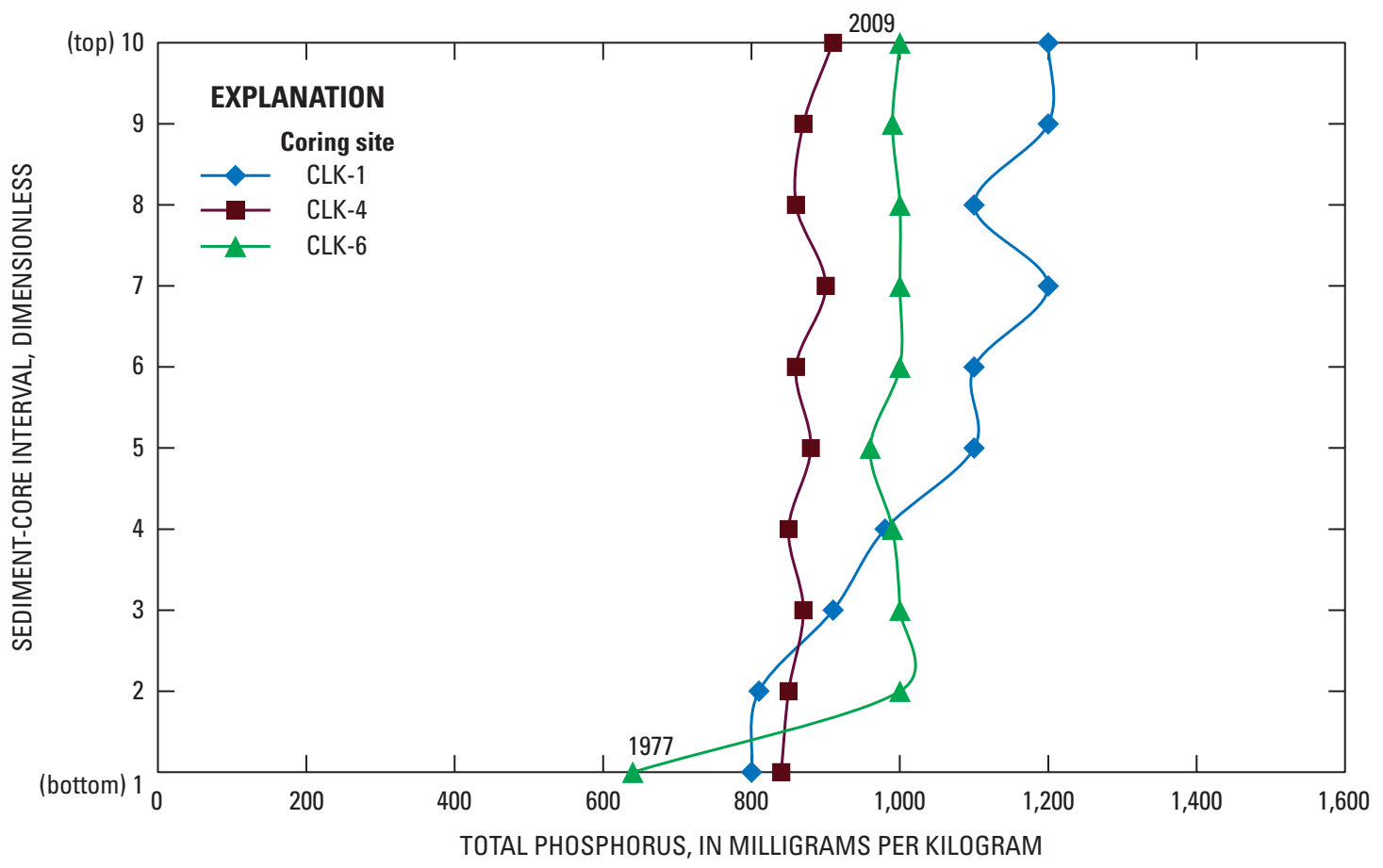

Figure 5. Variation in total phosphorus concentrations with depth of bottom-sediment samples collected from coring sites CLK-1, CLK-4, and CLK-6 in Clinton Lake, northeast Kansas, April 2009.

indicated that the Wakarusa River (larger basin, generally larger flows) possibly was a larger contributor of nitrogen and phosphorus to Clinton Lake than Rock Creek (fig. 2). Specifically, the median TN and TP concentrations for the core collected at site CLK-6 were 2,300 and $1,000 \mathrm{mg} / \mathrm{kg}$, respectively. In comparison, median TN and TP concentrations for the core collected at site CLK-4 were 2,100 and $865 \mathrm{mg} / \mathrm{kg}$, respectively. The possibility that the Wakarusa River delivers more nitrogen and phosphorus than Rock Creek was supported by water-column data from a study of Clinton Lake by Wang and others (2000). As part of their study, water-column samples were collected from the Wakarusa River, Deer Creek, and Rock Creek arms of Clinton Lake 17 times from May 1997 to November 1998 and analyzed for TN and TP. Median TN concentrations were $0.87 \mathrm{mg} / \mathrm{L}$ (milligrams per liter) for the Wakarusa River arm, $0.76 \mathrm{mg} / \mathrm{L}$ for the Deer Creek arm, and $0.68 \mathrm{mg} / \mathrm{L}$ for the Rock Creek arm of the reservoir. Median TP concentrations were $106 \mu \mathrm{g} / \mathrm{L}$ (micrograms per liter) for the Wakarusa River arm, $116 \mu \mathrm{g} / \mathrm{L}$ for the Deer Creek arm, and $88 \mu \mathrm{g} / \mathrm{L}$ for the Rock Creek arm of the reservoir (Wang and others, 2000). Land use, in terms of the percentage of cropland, grassland, and woodland, was similar for the Wakarusa River, Deer Creek, and Rock Creek subbasins (fig. 1).

Nutrient concentrations in sediment, as well as estimated nutrient yields, vary substantially throughout the State. For example, in a study of bottom sediments collected from 10 small reservoirs in eastern Kansas (and analyzed using the same laboratory methods as in this study), median TN and TP concentrations ranged from 1,400 to $3,700 \mathrm{mg} / \mathrm{kg}$ and from
550 to $1,300 \mathrm{mg} / \mathrm{kg}$, respectively. Mean annual net TN and TP yields, estimated for five of the small reservoirs, had respective ranges of 2,210 to $6,800\left(\mathrm{lb} / \mathrm{mi}^{2}\right) / \mathrm{yr}$ and 598 to $2,420\left(\mathrm{lb} / \mathrm{mi}^{2}\right) / \mathrm{yr}(J u r a c e k, 2004)$. Statistical analysis, with a significance level of 0.05 , indicated no significant correlations between median TN and TP concentrations in bottom sediment and land use. Likewise, a comparison of TN and TP yields with land use for the five small reservoirs for which nutrient yields were estimated also indicated no discernible relation (Juracek, 2004). In a national study of the effects of land use on sediment chemistry, Horowitz and Stephens (2008) determined that agricultural land use (cropland and pasture) had little or no effect on downstream sediment concentrations of several constituents including phosphorus and carbon. Several factors may, in part, explain why rural land use alone is not an effective predictor of nutrient concentrations in sediment. For example, a general land-use classification provides little or no information on such important factors as land-management practices (for example, tillage practices, grazing intensity), fertilizer application, and livestock and poultry production.

The variability in nutrient concentrations in sediment may be caused, in part, by factors for which information is not readily available. Such information includes background nutrient contributions from soils and bedrock, historical land-management practices, historical application of fertilizers, historical livestock production, sediment sources, and in-reservoir processes.

TOC concentrations generally were uniform within and between the three cores. With the exclusion of the same four 
Table 5. Results of trend tests on concentrations of selected chemical constituents in bottom-sediment samples collected from coring sites CLK-1, CLK-4, and CLK-6 in Clinton Lake, northeast Kansas, April 2009.

$[--$, not determined]

\begin{tabular}{|c|c|c|c|}
\hline \multirow{2}{*}{ Constituent } & \multicolumn{3}{|c|}{ Spearman's rho (two-sided p-value) } \\
\hline & CLK-1 1 & CLK-4 & CLK- $6^{2}$ \\
\hline \multicolumn{4}{|c|}{ Nutrients } \\
\hline Total nitrogen & $0.61(0.145)$ & $-0.49(0.146)$ & $-0.83(0.006)$ \\
\hline Total phosphorus & $.81(0.027)$ & $.70(0.023)$ & $.03(0.939)$ \\
\hline \multicolumn{4}{|c|}{ Carbon } \\
\hline Carbon, total organic & $.39(0.383)$ & $0(1.0)$ & $.18(0.638)$ \\
\hline Carbon, total & $.86(0.013)$ & $0(1.0)$ & $-.24(0.537)$ \\
\hline \multicolumn{4}{|c|}{ Trace elements } \\
\hline Aluminum & $.14(0.758)$ & $.75(0.012)$ & $.52(0.148)$ \\
\hline Antimony & $.77(0.044)$ & $-.52(0.122)$ & $.55(0.127)$ \\
\hline Arsenic & $.91(0.005)$ & $.66(0.037)$ & $.74(0.023)$ \\
\hline Barium & $.15(0.749)$ & $.38(0.273)$ & $0(1.0)$ \\
\hline Beryllium & $.18(0.701)$ & $.68(0.030)$ & $.66(0.051)$ \\
\hline Cadmium & $.66(0.106)$ & $-.16(0.668)$ & $.55(0.127)$ \\
\hline Chromium & $.18(0.699)$ & $.77(0.009)$ & $.50(0.168)$ \\
\hline Cobalt & $.90(0.006)$ & $.82(0.004)$ & $.91(0.0006)$ \\
\hline Copper & $-.17(0.718)$ & $.74(0.014)$ & $.61(0.084)$ \\
\hline Iron & $.36(0.434)$ & $.86(0.001)$ & $.83(0.006)$ \\
\hline Lead & $.80(0.030)$ & $.43(0.213)$ & $.06(0.869)$ \\
\hline Lithium & $.67(0.102)$ & $.86(0.001)$ & $.77(0.016)$ \\
\hline Manganese & $.96(0.0005)$ & $.75(0.013)$ & $.74(0.023)$ \\
\hline Molybdenum & -- & -- & -- \\
\hline Nickel & $.72(0.068)$ & $.89(0.0005)$ & $.84(0.004)$ \\
\hline Selenium & $.47(0.282)$ & $.06(0.864)$ & $0(1.0)$ \\
\hline Silver & -- & -- & -- \\
\hline Strontium & $0(--)$ & $.85(0.002)$ & $.64(0.064)$ \\
\hline Sulfur & $.33(0.474)$ & $.18(0.614)$ & $.28(0.464)$ \\
\hline Tin & $.13(0.775)$ & $.27(0.458)$ & $.26(0.500)$ \\
\hline Thallium & -- & -- & -- \\
\hline Titanium & $-.61(0.145)$ & $.08(0.822)$ & $-.19(0.618)$ \\
\hline Uranium & -- & -- & -- \\
\hline Vanadium & $-.06(0.899)$ & $.57(0.086)$ & $.46(0.217)$ \\
\hline Zinc & $.40(0.373)$ & $.50(0.143)$ & $.55(0.127)$ \\
\hline
\end{tabular}

${ }^{1}$ Top (most recently deposited) seven intervals of core used for trend analyses.

${ }^{2}$ Top (most recently deposited) nine intervals of core used for trend analyses.

core intervals previously noted, the respective ranges in TOC concentrations for the CLK-1, CLK-4, and CLK-6 cores were 1.7 to 2.0 percent, 1.6 to 1.8 percent, and 1.8 to 2.0 percent (tables A3, A4, and A5). A statistically significant trend in TOC concentrations was not indicated for any of the three cores (table 5).

\section{Trace Elements}

Generally, trace-element concentrations in the bottom sediment of Clinton Lake were uniform over time (tables A3, A4, and A5). A statistically significant positive trend was indicated for at least one coring site for several trace elements 


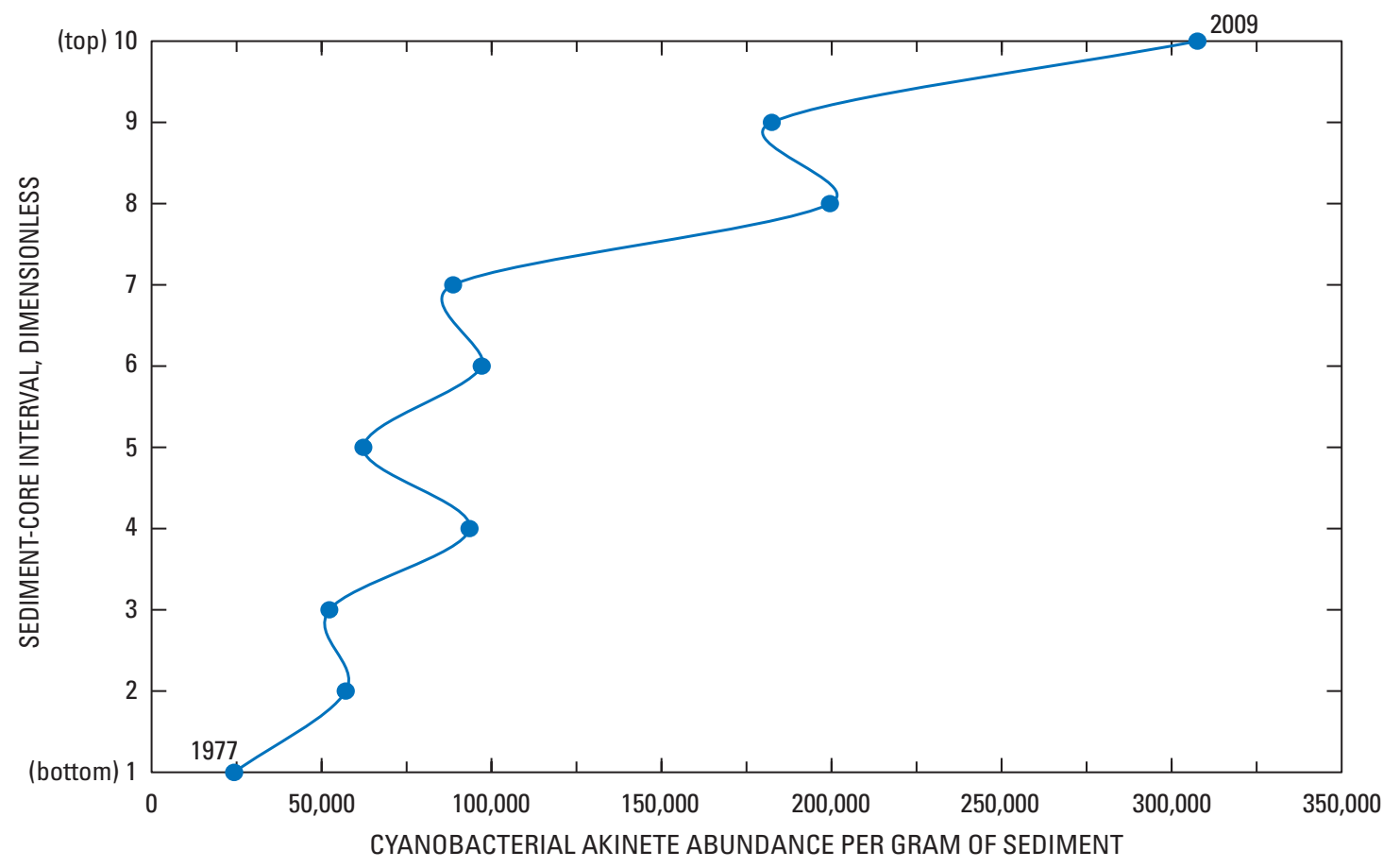

Figure 6. Variation in cyanobacterial akinete abundance with depth of bottom-sediment samples collected from coring site CLK-1 in Clinton Lake, northeast Kansas, April 2009.

(table 5). However, because for each element all or most of the core intervals had concentrations that were within 10 percent of the mean concentration, the trends may be a result of analytical variance.

Sediment quality was assessed for the eight trace elements for which SQGs were available (table 3). Silver was not detected in the bottom sediment of Clinton Lake. Cadmium, copper, and lead concentrations were less than the respective threshold-effects guidelines. With one exception, arsenic concentrations exceeded the threshold-effects guideline. All chromium and nickel concentrations exceeded the respective threshold-effects guidelines. Zinc concentrations frequently exceeded the threshold-effects guideline. No trace-element concentrations exceeded the probable-effects guidelines (tables 3, A3, A4, and A5).

Sediment concentrations of arsenic, chromium, and nickel greater than the respective threshold-effects guidelines are typical for reservoirs in eastern Kansas (Juracek, 2003, 2004, 2008, 2010; Juracek and Mau, 2002). For these three trace elements, the measured concentrations may be indicative of natural contributions from soils and bedrock.

\section{Cyanobacteria}

The core collected at site CLK-1 (fig. 2) was analyzed for cyanobacterial akinetes. The akinetes found were of the genus Anabaena, a cyanobacteria that is known to produce algal toxins and taste-and-odor compounds (Graham and others, 2008). Within the core, the occurrence of akinetes increased by more than an order of magnitude from about 24,300 per gram of sediment at the bottom of the core (oldest sediment) to about 308,000 per gram of sediment at the top of the core (most recently deposited sediment) (fig. 6). A statistically significant positive trend in akinete abundance was indicated (Spearman's rho $=0.92$, two-sided $p$-value $=0.0002$ ) .

The pronounced increase in akinete abundance indicated an increased presence of cyanobacteria in Clinton Lake that, in turn, provided possible evidence for increasingly eutrophic conditions in the reservoir. Because only certain taxa produce akinetes, an alternative possibility is that the increase in akinete abundance was indicative of a shift in the cyanobacteria population toward akinete producers (in this case, Anabaena). Several environmental factors affect cyanobacteria growth including light intensity (which is reduced by turbidity), nutrient availability, and temperature (Chorus and Bartram, 1999; Wetzel, 2001). Comprehensive historical data on these factors were not available to assess changes over the entire life of the reservoir. However, for two of the three sediment cores analyzed for nutrients (CLK-1 and CLK-4), a possible positive trend in TP deposition was indicated (fig. 5, table 5). Thus, the increase in akinete abundance may, in part, be related to increased phosphorus availability. It is noteworthy that cyanobacteria can out-compete other algal species in waters with nitrogen or phosphorus limitation or high turbidity (Chorus and Bartram, 1999). Clinton Lake tends to be nitrogen limited, which allows for cyanobacterial dominance in summer and fall (Kansas Department of Health and Environment, 2010). Given 
Table 6. Chlorophyll-a concentrations in Clinton Lake, northeast Kansas, 1979-2009. (Tom Stiles, Kansas

Department of Health and Environment, written commun., 2010).

[ppb, parts per billion; $\mathrm{m}$, meters]

\begin{tabular}{ccc}
\hline $\begin{array}{c}\text { Sample collection } \\
\text { date (month/day/year) }\end{array}$ & $\begin{array}{c}\text { Chlorophyll-a con- } \\
\text { centration' } \mathbf{( p p b )}\end{array}$ & $\begin{array}{c}\text { Sampling depth } \\
(\mathbf{m})\end{array}$ \\
\hline $07 / 09 / 1979$ & 4.5 & 0 \\
$07 / 14 / 1981$ & 10.5 & 0 \\
$06 / 15 / 1988$ & 19.4 & 0.5 \\
$\mathbf{1 9 8 0 s}$ mean & $\mathbf{1 5 . 0}$ & \\
$06 / 10 / 1991$ & 22.3 & .5 \\
$05 / 17 / 1994$ & 14.1 & .5 \\
$08 / 07 / 1996$ & 11.1 & .5 \\
$07 / 16 / 1997$ & 10.3 & .5 \\
$06 / 16 / 1998$ & 31.7 & .5 \\
1990s mean & $\mathbf{1 7 . 9}$ & \\
$08 / 09 / 2000$ & 16.6 & .5 \\
$07 / 15 / 2003$ & 33.6 & .5 \\
$06 / 19 / 2006$ & 13.2 & .5 \\
$08 / 10 / 2009$ & 24.5 & .5 \\
$\mathbf{2 0 0 0 s}$ mean & $\mathbf{2 2 . 0}$ & \\
\hline
\end{tabular}

${ }^{1}$ Beginning in 1988, the chlorophyll-a concentration listed for each sampling date is the average of two replicate samples.

the abundance of cyanobacterial akinetes, it is likely that algal blooms occur in the reservoir that may produce taste-andodor compounds and possibly algal toxins. This conclusion was substantiated by the fact that taste-and-odor compounds (typically geosmin produced by the cyanobacteria Anabaena) have been a periodic occurrence at Clinton Lake since at least the 1980s (Jeanette Klamm, city of Lawrence, oral commun., 2010).

Chlorophyll-a is used as a surrogate indicator of eutrophication (Wetzel, 2001; Wehr and Sheath, 2003). As part of its Lake and Wetland Monitoring Program, KDHE sampled the water in Clinton Lake one day during the late spring or summer approximately every 3 years from 1979 to 2009 . During that 30-year period, chlorophyll-a concentrations at or near the water surface ranged from 4.5 to $33.6 \mathrm{ppb}$ (parts per billion) and typically were larger than $10 \mathrm{ppb}$ (table 6) (Tom Stiles, Kansas Department of Health and Environment, written commun., 2010). KDHE classifies the trophic condition of a lake using the following chlorophyll-a criteria: oligotrophic (0 to $2.4 \mathrm{ppb}$ ), mesotrophic (2.4 to $7.2 \mathrm{ppb}$ ), slightly eutrophic

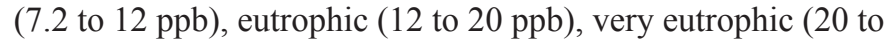
$30 \mathrm{ppb}$ ), and hypereutrophic (greater than $30 \mathrm{ppb}$ ) (Ed Carney, Kansas Department of Health and Environment, written commun., 2007). Based on these criteria, the trophic condition of Clinton Lake generally varied from mesotrophic to hypereutrophic from 1979 to 2009 (table 6).
To provide some perspective on trends, the KDHE chlorophyll-a data for the surface or near-surface sampling depths were averaged to provide decadal means. In 1979, the chlorophyll-a concentration for a single surface sample was $4.5 \mathrm{ppb}$. Subsequently, mean chlorophyll-a concentrations at or near the water surface for the 1980s (two sampling dates), 1990s (five sampling dates), and 2000s (four sampling dates) were 15.0, 17.9, and $22.0 \mathrm{ppb}$, respectively (table 6). Though based on limited data, the decadal means indicated a shift from mesotrophic to very eutrophic conditions according to the KDHE classification. Together, the chlorophyll-a and cyanobacteria data indicated that Clinton Lake possibly has become more eutrophic over time.

Clinton Lake also was classified as eutrophic throughout its history based on the total phosphorus content in the water (Wetzel, 2001). From 1979 to 2009, measurements made by KDHE during the late spring or summer about once every 3 years indicated that total phosphorus concentrations at or near the water surface ranged from 0.01 to $0.15 \mathrm{mg} / \mathrm{L}$ (Tom Stiles, Kansas Department of Health and Environment, written commun., 2010).

\section{Summary and Conclusions}

A 2-year study by the U.S. Geological Survey, in cooperation with the Kansas Department of Health and Environment, was begun in 2008 to investigate sedimentation in Clinton Lake and the deposition of selected chemical constituents and cyanobacterial akinetes (cyanobacteria resting stage) in the bottom sediment of the reservoir for 1977 through 2009. The study used a combination of available bathymetric-survey information and bottom-sediment coring completed in 2009. The major results of this study are listed below:

1. The total estimated volume and mass of bottom sediment in the conservation pool of Clinton Lake was 438 million $\mathrm{ft}^{3}$ and 18 billion $\mathrm{lb}$, respectively.

2. The estimated sediment volume occupied about 8 percent of the conservation-pool, water-storage capacity of Clinton Lake. Water-storage capacity in the conservation pool has been lost to sedimentation at a rate of about 0.25 percent annually.

3. The mean annual sedimentation rate in the conservation pool of Clinton Lake is about 70 percent larger than originally projected when the reservoir was completed.

4. Mean annual net sediment deposition in the conservation pool of Clinton Lake was estimated to be 563 million lb/ yr.

5. Mean annual net sediment yield from the Clinton Lake Basin was estimated to be 1.5 million $\left(\mathrm{lb} / \mathrm{mi}^{2}\right) / \mathrm{yr}$.

6. Total nitrogen in the bottom sediment of Clinton Lake generally was uniform over time, with a median concen- 
tration of $2,300 \mathrm{mg} / \mathrm{kg}$, and indicated consistent inputs to the reservoir.

7. The mean annual net load and yield of total nitrogen deposited in the bottom sediment of Clinton Lake was estimated to be 1.29 million $\mathrm{lb} / \mathrm{yr}$ and $3,510\left(\mathrm{lb} / \mathrm{mi}^{2}\right) / \mathrm{yr}$, respectively.

8. Total phosphorus in the bottom sediment of Clinton Lake generally was uniform over time with a median concentration of $990 \mathrm{mg} / \mathrm{kg}$; although, a possible increase in inputs to the reservoir was indicated. As a principal limiting factor for primary production in most freshwater environments, phosphorus is of particular importance because increased inputs can contribute to accelerated reservoir eutrophication and the production of algal toxins and taste-and-odor compounds.

9. The mean annual net load and yield of total phosphorus deposited in the bottom sediment of Clinton Lake was estimated to be $556,000 \mathrm{lb} / \mathrm{yr}$ and $1,510\left(\mathrm{lb} / \mathrm{mi}^{2}\right) / \mathrm{yr}$, respectively.

10. The Wakarusa River possibly was a larger contributor of nitrogen and phosphorus to Clinton Lake than was Rock Creek.

11. Trace element concentrations in the bottom sediment of Clinton Lake generally were uniform over time.

12. As is typical for eastern Kansas reservoirs, arsenic, chromium, and nickel concentrations in the bottom sediment of Clinton Lake typically exceeded the threshold-effects guidelines, which represent the concentrations above which toxic biological effects occasionally occur.

13. Trace element concentrations did not exceed the probableeffects guidelines (available for eight trace elements), which represent the concentrations above which toxic biological effects usually or frequently occur.

14. Occurrence of cyanobacterial akinetes in the bottom sediment of Clinton Lake, combined with historical water-quality data on chlorophyll-a and total phosphorus concentrations, indicated that the reservoir likely has been eutrophic throughout most of its history.

15. A statistically significant increase in cyanobacterial akinetes in the bottom sediment indicated that Clinton Lake may have become more eutrophic over the life of the reservoir. The increase in cyanobacterial akinetes may, in part, be related to a possible increase in total phosphorus concentrations.

\section{References Cited}

Adams, D.G., and Duggan, P.S., 1999, Tansley review No. 107 , Heterocyst and akinete differentiation in cyanobacteria: New Phytology, v. 144, p. 3-33.

Adriano, D.C., 2001, Trace elements in terrestrial environments-Biogeochemistry, bioavailability, and risks of metals (2d ed.): New York, Springer-Verlag, 866 p.

Agency for Toxic Substances and Disease Registry, 2010, CERCLA priority list of hazardous substances: accessed April 2010 at http://www.atsdr.cdc.gov/cercla/07list.html.

Arbogast, B.F., 1996, Analytical methods manual for the Mineral Resource Surveys Program: U.S. Geological Survey Open-File Report 96-525, 248 p.

Baudo, Renato, Giesy, J.P., and Muntau, Herbert, eds., 1990, Sediments - Chemistry and toxicity of in-place pollutants: Ann Arbor, Michigan, Lewis Publishers, 405 p.

Blomqvist, Sven, 1985, Reliability of core sampling of soft bottom sediment - an in situ study: Sedimentology, v. 32, p. 605-612.

Blomqvist, Sven, and Bostrom, Kurt, 1987, Improved sampling of soft bottom sediments by combined box and piston coring: Sedimentology, v. 34, p. 715-719.

Briggs, P.H., and Meier, A.L., 1999, The determination of forty two elements in geological materials by inductively coupled plasma-mass spectrometry: U.S. Geological Survey Open-File Report 99-166, 15 p.

Brune, G.M., 1953, Trap efficiency of reservoirs: Transactions of the American Geophysical Union, v. 34, p. 407-448.

Charles, M.J., and Hites, R.A., 1987, Sediments as archives of environmental pollution trends, chap. 12, in Hites, R.A., and Eisenreich, S.J., eds., Sources and fates of aquatic pollutants: Washington, D.C., American Chemical Society, Advances in Chemistry Series 216, p. 365-389.

Chorus, Ingrid, and Bartram, Jamie, eds., 1999, Toxic cyanobacteria in water-A guide to their public health consequences, monitoring and management: London, E \& FN Spon, 416 p.

Cole, G.A., 1994, Textbook of limnology (4th ed.): Prospect Heights, Illinois, Waveland Press, Inc., 412 p.

Cronberg, Gertrud, 1986, Blue-green algae, green algae and chrysophyceae in sediments, chap. 25, in Berglund, B.E., ed., Handbook of Holocene Palaeoecology and Palaeohydrology: Chichester, England, John Wiley \& Sons, p. 507-526. 
Davies, B.E., 1983, Heavy metal contamination from base metal mining and smelting-Implications for man and his environment, chap. 14, in Thornton, Iain, ed., Applied Environmental Geochemistry: New York, Academic Press, $501 \mathrm{p}$.

Dillon, P.J., and Rigler, F.H., 1974, The phosphorus-chlorophyll relationship in lakes: Limnology and Oceanography, v. 19 , p. $767-773$.

Emery, K.O., and Hulsemann, J., 1964, Shortening of sediment cores collected in open barrel gravity corers: Sedimentology, v. 3, p. 144-154.

Fenneman, N.M., 1946, Physical divisions of the United States: U.S. Geological Survey special map, scale 1:7,000,000, 1 sheet.

Fishman, M.J., and Friedman, L.C., eds., 1989, Methods for determination of inorganic substances in water and fluvial sediments: U.S. Geological Survey Techniques of WaterResources Investigations, book 5, chap. A1, 545 p.

Forstner, Ulrich, and Wittmann, G.T.W., 1981, Metal pollution in the aquatic environment: New York, Springer-Verlag, $486 \mathrm{p}$.

Gordon, N.D., McMahon, T.A., and Finlayson, B.L., 1992, Stream hydrology - An introduction for ecologists: New York, John Wiley \& Sons, $526 \mathrm{p}$.

Graham, J.L., Loftin, K.A., Ziegler, A.C., and Meyer, M.T., 2008, Guidelines for design and sampling for cyanobacterial toxin and taste-and-odor studies in lakes and reservoirs: U.S. Geological Survey Scientific Investigations Report 2008-5038, 39 p.

Guy, H.P., 1969, Laboratory theory and methods for sediment analysis: U.S. Geological Survey Techniques of WaterResources Investigations, book 5, chap. C1, 58 p.

Hakanson, L., and Jansson, M., 1983, Principles of lake sedimentology: New York, Springer-Verlag, $316 \mathrm{p}$.

He, Q., and Owens, P., 1995, Determination of suspended sediment provenance using caesium-137, unsupported lead210 and radium-226-A numerical mixing model approach, chapter 12, in Foster, I., Gurnell, A., and Webb, B., eds., Sediment and Water Quality in River Catchments: New York, John Wiley \& Sons, p. 207-227.

Helsel, D.R., and Hirsch, R.M., 1992, Statistical methods in water resources: Amsterdam, Elsevier Science Publishers, $529 \mathrm{p}$.

Hem, J.D., 1989, Study and interpretation of the chemical characteristics of natural water (3d ed.): U.S. Geological Survey Water-Supply Paper 2254, 263 p.
High Plains Regional Climate Center, 2010, Historical data summaries: accessed May 2010 at http://www.hprcc.unl. $e d u /$.

Holmes, C.W., Robbins, J., Halley, R., Bothner, M., Ten Brink, M., and Marot, M., 2001, Sediment dynamics of Florida Bay mud banks on a decadal time scale: Bulletins of American Paleontology, no. 361, p. 31-40.

Hongve, Dag, and Erlandsen, A.H., 1979, Shortening of surface sediment cores during sampling: Hydrobiologia, v. 65, no. 3, p. 283-287.

Horne, A.J., and Goldman, C.R., 1994, Limnology (2d ed.): New York, McGraw-Hill, Inc., 576 p.

Horowitz, A.J., 1991, A primer on sediment-trace element chemistry ( $2 \mathrm{~d}$ ed.): Chelsea, Michigan, Lewis Publ., 136 p.

Horowitz, A.J., Elrick, K.A., and Smith, J.J., 2001, Estimating suspended sediment and trace element fluxes in large river basins-Methodological considerations as applied to the NASQAN program: Hydrological Processes, v. 15, p. $1,107-1,132$.

Horowitz, A.J., and Stephens, V.C., 2008, The effects of land use on fluvial sediment chemistry for the conterminous U.S.- - Results from the first cycle of the NAWQA program: Trace and major elements, phosphorus, carbon, and sulfur: Science of the Total Environment, v. 400, p. 290-314.

Jones, J.R., and Bachmann, R.W., 1976, Prediction of phosphorus and chlorophyll levels in lakes: Journal Water Pollution Control Federation, v. 48, p. 2,176-2,182.

Jones, J.R., Obrecht, D.V., Perkins, B.D., Knowlton, M.F., Thorpe, A.P., Watanabe, Shohei, and Bacon, R.R., 2008, Nutrients, seston, and transparency of Missouri reservoirs and oxbow lakes-An analysis of regional limnology: Lake and Reservoir Management, v. 24, p. 155-180.

Jordan, P.R., and Stamer, J.K., eds., 1995, Surface-water-quality assessment of the lower Kansas River Basin, Kansas and Nebraska-Analysis of available data through 1986: U.S. Geological Survey Water-Supply Paper 2352-B, 161 p.

Juracek, K.E., 2003, Sediment deposition and occurrence of selected nutrients, other chemical constituents, and diatoms in bottom sediment, Perry Lake, northeast Kansas, 19692001: U.S. Geological Survey Water-Resources Investigations Report 03-4025, 56 p.

Juracek, K.E., 2004, Sedimentation and occurrence and trends of selected chemical constituents in bottom sediment of 10 small reservoirs, eastern Kansas: U.S. Geological Survey Scientific Investigations Report 2004-5228, 80 p. 
Juracek, K.E., 2008, Sedimentation and occurrence and trends of selected nutrients, other chemical constituents, and diatoms in bottom sediment, Fall River Lake, southeast Kansas, 1948-2006: U.S. Geological Survey Scientific Investigations Report 2008-5019, 29 p.

Juracek, K.E., 2010, Sedimentation, sediment quality, and upstream channel stability, John Redmond Reservoir, east-central Kansas, 1964-2009: U.S. Geological Survey Scientific Investigations Report 2010-5191, 34 p.

Juracek, K.E., and Mau, D.P., 2002, Sediment deposition and occurrence of selected nutrients and other chemical constituents in bottom sediment, Tuttle Creek Lake, northeast Kansas, 1962-99: U.S. Geological Survey Water-Resources Investigations Report 02-4048, 73 p.

Juracek, K.E., and Ziegler, A.C., 2006, The legacy of leaded gasoline in bottom sediment of small rural reservoirs: Journal of Environmental Quality, v. 35, p. 2,092-2,102.

Juracek, K.E., and Ziegler, A.C., 2007, Estimation of sediment sources using selected chemical tracers in the Perry Lake and Lake Wabaunsee Basins, northeast Kansas: U.S. Geological Survey Scientific Investigations Report 2007-5020, $53 \mathrm{p}$.

Juracek, K.E., and Ziegler, A.C., 2009, Estimation of sediment sources using selected chemical tracers in the Perry Lake Basin, Kansas, USA: International Journal of Sediment Research, v. 24, p. 108-125.

Kansas Applied Remote Sensing Program, 2009, 2005 Kansas land cover patterns, scale 1:50,000: accessed June 2010 at http://www.kansasgis.org.

Kansas Biological Survey, 2010, Bathymetric and sediment survey of Clinton Lake reservoir, Douglas County, Kansas: Kansas Biological Survey Applied Science and Technology for Reservoir Assessment Program Report 2009-09, 27 p.

Kansas Department of Health and Environment, 2010, 303(d) methodology and list: accessed May 2010 at $h t t p: / / w w w$. kdheks.gov/tmdl/methodology.htm.

Kansas Water Office, 2010, Clinton Lake, Reservoir information sheet: accessed May 2010 at http://www.kwo.org/ ReservoirInformation/ReservoirFactSheets/2010/Rpt_Clinton_2010.pdf.

Karickhoff, S.W., 1984, Organic pollutant sorption in aquatic systems: Journal of Hydraulic Engineering, v. 110, no. 6, p. $707-735$.

Kling, H.J., 1998, A summary of past and recent plankton of Lake Winnipeg, Canada using algal fossil remains: Journal of Paleolimnology, v. 19, p. 297-307.
Lee, C.J., Rasmussen, P.P., and Ziegler, A.C., 2008, Characterization of suspended-sediment loading to and from John Redmond Reservoir, east-central Kansas, 2007-2008: U.S. Geological Survey Scientific Investigations Report 20085123, $25 \mathrm{p}$.

Lide, D.R., ed., 1993, CRC handbook of chemistry and physics (74th ed.): Boca Raton, Florida, CRC Press, various pagination.

Livingstone, David, and Jaworski, G.H.M., 1980, The viability of akinetes of blue-green algae recovered from the sediments of Rostherne Mere: European Journal of Phycology, v. 15, p. $357-364$.

Luoma, S.N., and Rainbow, P.S., 2008, Metal contamination in aquatic environments-Science and lateral management: New York, Cambridge University Press, 573 p.

MacDonald, D.D., Ingersoll, C.G., and Berger, T.A., 2000, Development and evaluation of consensus-based sediment quality guidelines for freshwater ecosystems: Archives of Environmental Contamination and Toxicology, v. 39, p. 20-31.

Marmiroli, Nelson, and Maestri, Elena, 2008, Health implications of trace elements in the environment and the food chain, chap. 2, in Prasad, M.N.V., ed., Trace elements as contaminants and nutrients - Consequences in ecosystems and human health: Hoboken, New Jersey, John Wiley \& Sons, p. 23-53.

Morris, G.L., and Fan, Jiahua, 1998, Reservoir sedimentation handbook: New York, McGraw-Hill, various pagination.

Pais, Istvan, and Jones, J.B., Jr., 1997, The handbook of trace elements: Boca Raton, Florida, St. Lucie Press, 223 p.

Rasanen, Johanna, Kauppila, Tommi, and Vuorio, Kristiina, 2006, Sediment and phytoplankton records of the cyanobacterial genus Anabaena in boreal Lake Pyhajarvi: Hydrobiologia, v. 568, p. 455-465.

Ritchie, J.C., and McHenry, J.R., 1990, Application of radioactive fallout cesium-137 for measuring soil erosion and sediment accumulation rates and patterns-A review: Journal of Environmental Quality, v. 19, p. 215-233.

Schoewe, W.H., 1949, The geography of Kansas: Transactions Kansas Academy of Science, v. 52, p. 261-333.

Shotbolt, L.A., Thomas, A.D., and Hutchinson, S.M., 2005, The use of reservoir sediments as environmental archives of catchment inputs and atmospheric pollution: Progress in Physical Geography, v. 29, p. 337-361.

Smol, J.P., 2002, Pollution of lakes and rivers-A paleoenvironmental perspective: New York, Oxford University Press, $280 \mathrm{p}$. 
U.S. Army Corps of Engineers, 1979, Lower Kansas River Basin lake regulation manual, volume 4, Clinton Lake: Kansas City, Missouri, U.S. Army Corps of Engineers, Kansas City District, December 1979, various pagination.

U.S. Department of Agriculture, Soil Conservation Service, 1970, Soil survey of Shawnee County, Kansas: U.S. Department of Agriculture, Soil Conservation Service, 77 p.

U.S. Department of Agriculture, Soil Conservation Service, 1977, Soil survey of Douglas County, Kansas: U.S. Department of Agriculture, Soil Conservation Service, 73 p.

U.S. Department of Agriculture, Soil Conservation Service, 1985, Soil survey of Osage County, Kansas: U.S. Department of Agriculture, Soil Conservation Service, 100 p.

U.S. Department of Agriculture, Soil Conservation Service, 1991, Soil survey of Wabaunsee County, Kansas: U.S. Department of Agriculture, Soil Conservation Service, $132 \mathrm{p}$.

U.S. Environmental Protection Agency, 1991, Guidance of water quality-based decisions - the TMDL process: Washington, D.C., Office of Water, EPA440/4-91-001, 59 p.

U.S. Environmental Protection Agency, 1997, The incidence and severity of sediment contamination in surface waters of the United States, volume 1-National sediment quality survey: U.S. Environmental Protection Agency Report 823-R-97-006, September 1997, various pagination.

van Geel, B., Mur, L.R., Ralska-Jasiewiczowa, M., and Goslar, T., 1994, Fossil akinetes of Aphanizomenon and Anabaena as indicators for medieval phosphate-eutrophication of Lake Gosciaz (Central Poland): Review of Palaeobotany and Palynology, v. 83, p. 97-105.

Van Metre, P.C., and Callender, Edward, 1996, Identifying water-quality trends in the Trinity River, Texas, USA, 1969-1992, using sediment cores from Lake Livingston: Environmental Geology, v. 28, no. 4, p. 190-200.

Van Metre, P.C., Callender, Edward, and Fuller, C.C., 1997, Historical trends in organochlorine compounds in river basins identified using sediment cores from reservoirs: Environmental Science \& Technology, v. 31, no. 8, p. 2,339-2,344.
Van Metre, P.C., and Mahler, B.J., 2004, Contaminant trends in reservoir sediment cores as records of influent stream quality: Environmental Science \& Technology, v. 38, p. 2,978-2,986.

Vanoni, V.A., ed., 2006, Sedimentation engineering: Reston, Virginia, American Society of Civil Engineers, 418 p.

Walling, D.E., and Woodward, J.C., 1995, Tracing sources of suspended sediment in river basins - A case study of the River Culm, Devon, UK: Marine and Freshwater Research, v. 46, p. 327-336.

Wang, S.H., Huggins, D.G., deNoyelles, Frank, Meyer, J.O., and Lennon, J.T., 2000, Assessment of Clinton Lake and its watershed-Water quality and plankton communities in Clinton Lake, Kansas May 1997 through November 1998: Kansas Biological Survey Report 96, 95 p.

Wehr, J.D., and Sheath, R.G., eds., 2003, Freshwater algae of North America-Ecology and classification: New York, Academic Press, 918 p.

Wetzel, R.G., 2001, Limnology_Lake and river ecosystems (3d ed.): New York, Academic Press, 1,006 p.

Williams, G.P, and Wolman, M.G., 1984, Downstream effects of dams on alluvial rivers: U.S. Geological Survey Professional Paper 1286, 83 p.

Wise, S.M., 1980, Caesium-137 and lead-210-A review of the techniques and some applications in geomorphology, chap. 9, in Cullingford, R.A., Davidson, D.A., and Lewin, J., eds., Timescales in Geomorphology: New York, John Wiley \& Sons, 360 p.

Zoumis, Theofanis, Schmidt, Astrid, Grigorova, Lidia, and Calmano, Wolfgang, 2001, Contaminants in sedimentsremobilisation and demobilisation: The Science of the Total Environment, v. 266, p. 195-202. 
Supplemental Information 
24 Sedimentation and Occurrence and Trends of Selected Constituents in Clinton Lake, Northeast Kansas, 1977-2009

Table A1. Latitude and longitude coordinates, water depth, estimated penetration depth, length of recovered core, and estimated recovery percentage for bottom-sediment coring sites at Clinton Lake, northeast Kansas.

\begin{tabular}{|c|c|c|c|c|c|c|c|}
\hline $\begin{array}{l}\text { Coring site } \\
\text { number } \\
\text { (fig. 2) }\end{array}$ & $\begin{array}{c}\text { Date cored } \\
\text { (month/day/ } \\
\text { year) }\end{array}$ & $\begin{array}{l}\text { Latitude } \\
\text { (decimal } \\
\text { degrees) }\end{array}$ & $\begin{array}{c}\text { Longitude } \\
\text { (decimal } \\
\text { degrees) }\end{array}$ & $\begin{array}{l}\text { Water depth } \\
\text { (feet) }\end{array}$ & $\begin{array}{l}\text { Estimated } \\
\text { penetration } \\
\text { depth (feet) }\end{array}$ & $\begin{array}{l}\text { Length of } \\
\text { recovered core } \\
\text { (feet) }\end{array}$ & $\begin{array}{c}\text { Estimated } \\
\text { recovery per- } \\
\text { centage }\end{array}$ \\
\hline CLK-1 & $04 / 15 / 09$ & 38.92472 & 95.34417 & 46.0 & 8.0 & 5.4 & 68 \\
\hline CLK-2 & 06/11/09 & 38.91014 & 95.34775 & 37.0 & 6.0 & 4.5 & 75 \\
\hline CLK-3 & 06/11/09 & 38.89847 & 95.36944 & 28.0 & 11.5 & 8.7 & 76 \\
\hline CLK-6 & 04/15/09 & 38.92250 & 95.41389 & 26.0 & 9.0 & 7.0 & 78 \\
\hline CLK-7 & 06/11/09 & 38.90653 & 95.42942 & 11.0 & 9.0 & 6.0 & 67 \\
\hline CLK-8 & 06/25/09 & 38.88694 & 95.40333 & 13.0 & 10.0 & 6.6 & 66 \\
\hline
\end{tabular}


Table A2. Estimated bulk density of bottom sediment at coring sites in Clinton Lake, northeast Kansas.

[lb/ft ${ }^{3}$, pounds per cubic foot; --, not applicable]

\begin{tabular}{|c|c|c|c|}
\hline $\begin{array}{l}\text { Coring site } \\
\text { number } \\
\text { (fig. 2) }\end{array}$ & $\begin{array}{c}\text { Depth } \\
\text { interval } \\
\text { (feet) }\end{array}$ & $\begin{array}{c}\text { Estimated } \\
\text { bulk density } \\
\left(\mathrm{lb} / \mathrm{ft}^{3}\right)\end{array}$ & $\begin{array}{c}\text { Computed } \\
\text { mean bulk } \\
\text { density }{ }^{1} \\
\left(\mathrm{Ib}^{\prime} / \mathrm{ft}^{3}\right)\end{array}$ \\
\hline \multirow[t]{11}{*}{ CLK-1 } & $0-0.87$ & 21.0 & -- \\
\hline & $0.87-1.74$ & 23.1 & -- \\
\hline & $1.74-2.61$ & 24.4 & -- \\
\hline & $2.61-3.48$ & 24.6 & -- \\
\hline & $3.48-4.35$ & 29.8 & -- \\
\hline & $4.35-5.22$ & 31.7 & -- \\
\hline & $5.22-6.09$ & 30.2 & -- \\
\hline & $6.09-6.96$ & 36.2 & -- \\
\hline & $6.96-7.83$ & 36.1 & -- \\
\hline & $7.83-8.70$ & 44.6 & -- \\
\hline & & & 30.2 \\
\hline \multirow[t]{4}{*}{ CLK-2 } & $0-0.93$ & 23.9 & -- \\
\hline & $0.93-1.86$ & 35.2 & -- \\
\hline & $1.86-2.79$ & 58.3 & -- \\
\hline & & & 39.1 \\
\hline \multirow[t]{10}{*}{ CLK-3 } & $0-0.92$ & 28.2 & -- \\
\hline & $0.92-1.84$ & 31.6 & -- \\
\hline & $1.84-2.76$ & 33.0 & -- \\
\hline & $2.76-3.68$ & 35.4 & -- \\
\hline & $3.68-4.60$ & 40.1 & -- \\
\hline & $4.60-5.52$ & 42.1 & -- \\
\hline & $5.52-6.44$ & 37.7 & -- \\
\hline & $6.44-7.36$ & 42.7 & -- \\
\hline & $7.36-8.28$ & 44.2 & -- \\
\hline & & & 37.2 \\
\hline \multirow[t]{7}{*}{ CLK-4 } & $0-0.93$ & 31.3 & -- \\
\hline & $0.93-1.86$ & 33.4 & -- \\
\hline & $1.86-2.79$ & 39.1 & -- \\
\hline & $2.79-3.72$ & 42.9 & -- \\
\hline & $3.72-4.65$ & 45.8 & -- \\
\hline & $4.65-5.58$ & 46.0 & -- \\
\hline & & & 39.8 \\
\hline
\end{tabular}

\begin{tabular}{|c|c|c|c|}
\hline $\begin{array}{c}\text { Coring site } \\
\text { number } \\
\text { (fig. 2) }\end{array}$ & $\begin{array}{c}\text { Depth } \\
\text { interval } \\
\text { (feet) }\end{array}$ & $\begin{array}{c}\text { Estimated } \\
\text { bulk density } \\
\left(\mathrm{lb} / \mathrm{ft}^{3}\right)\end{array}$ & $\begin{array}{c}\text { Computed } \\
\text { mean bulk } \\
\text { density } \\
\left(\mathrm{lb} / \mathrm{ft}^{3}\right)\end{array}$ \\
\hline \multirow[t]{9}{*}{ CLK-5 } & $0-1.02$ & 26.0 & -- \\
\hline & $1.02-2.04$ & 28.0 & -- \\
\hline & $2.04-3.06$ & 29.4 & -- \\
\hline & $3.06-4.08$ & 33.1 & -- \\
\hline & $4.08-5.10$ & 34.2 & -- \\
\hline & $5.10-6.12$ & 39.1 & -- \\
\hline & $6.12-7.14$ & 38.9 & -- \\
\hline & $7.14-8.16$ & 43.3 & -- \\
\hline & & & 34.0 \\
\hline \multirow[t]{8}{*}{ CLK-6 } & $0-1.03$ & 28.8 & -- \\
\hline & $1.03-2.06$ & 31.0 & -- \\
\hline & $2.06-3.09$ & 33.0 & -- \\
\hline & $3.09-4.12$ & 35.8 & -- \\
\hline & $4.12-5.15$ & 39.8 & -- \\
\hline & $5.15-6.18$ & 43.0 & -- \\
\hline & $6.18-7.20$ & 48.1 & -- \\
\hline & & & 37.1 \\
\hline \multirow[t]{7}{*}{ CLK-7 } & $0-0.97$ & 45.2 & -- \\
\hline & $0.97-1.94$ & 52.6 & -- \\
\hline & $1.94-2.91$ & 60.5 & -- \\
\hline & $2.91-3.88$ & 52.4 & -- \\
\hline & $3.88-4.85$ & 59.5 & -- \\
\hline & $4.85-5.82$ & 59.1 & -- \\
\hline & & & 54.9 \\
\hline \multirow[t]{7}{*}{ CLK-8 } & $0-1.02$ & 38.9 & -- \\
\hline & $1.02-2.04$ & 50.6 & -- \\
\hline & $2.04-3.06$ & 49.7 & -- \\
\hline & $3.06-4.08$ & 51.7 & -- \\
\hline & $4.08-5.10$ & 55.8 & -- \\
\hline & $5.10-6.12$ & 65.4 & -- \\
\hline & & & 52.0 \\
\hline
\end{tabular}

${ }^{1}$ Mean bulk density computed as the average of the bulk densities for the individual depth intervals for each core. 


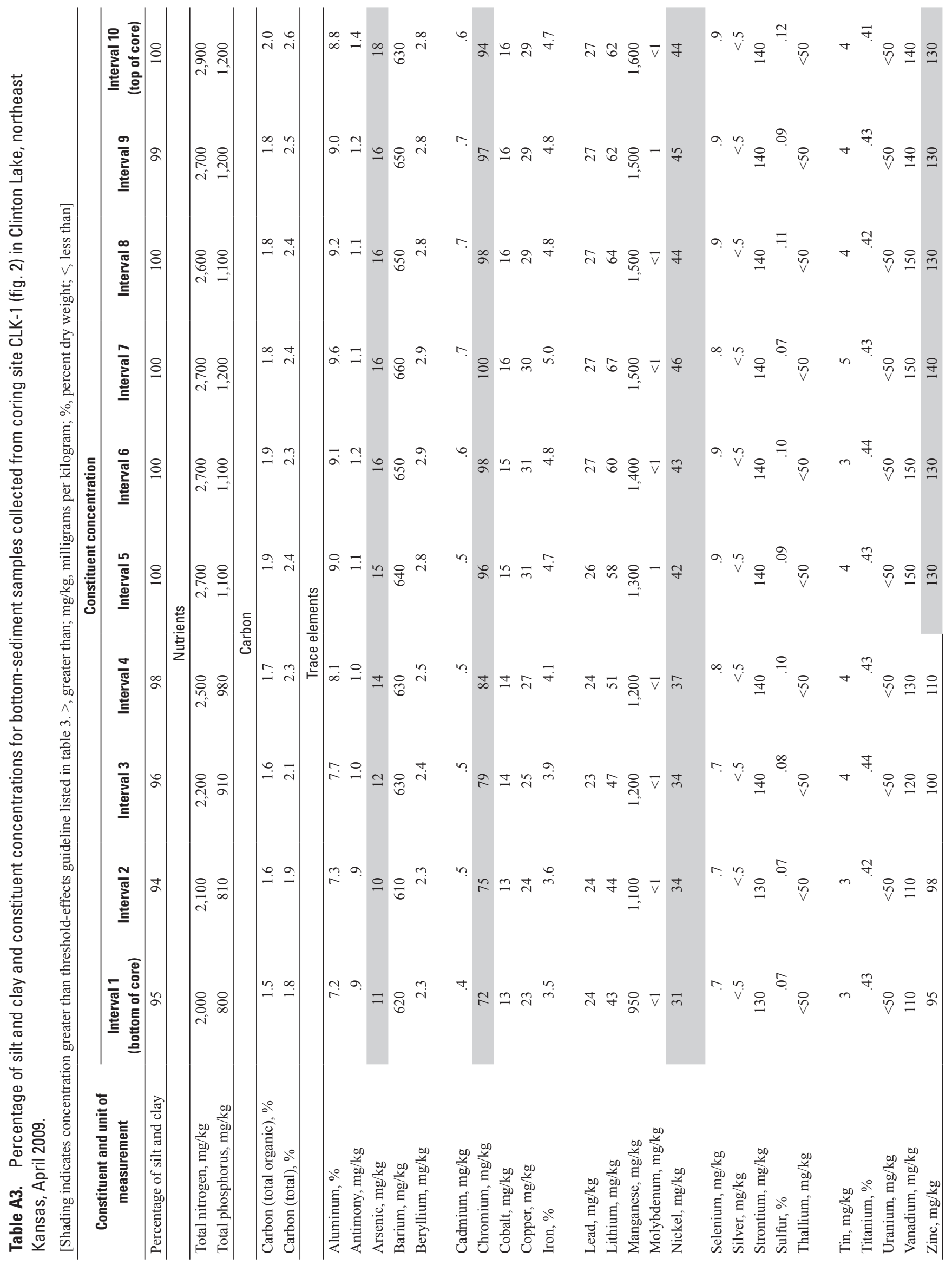




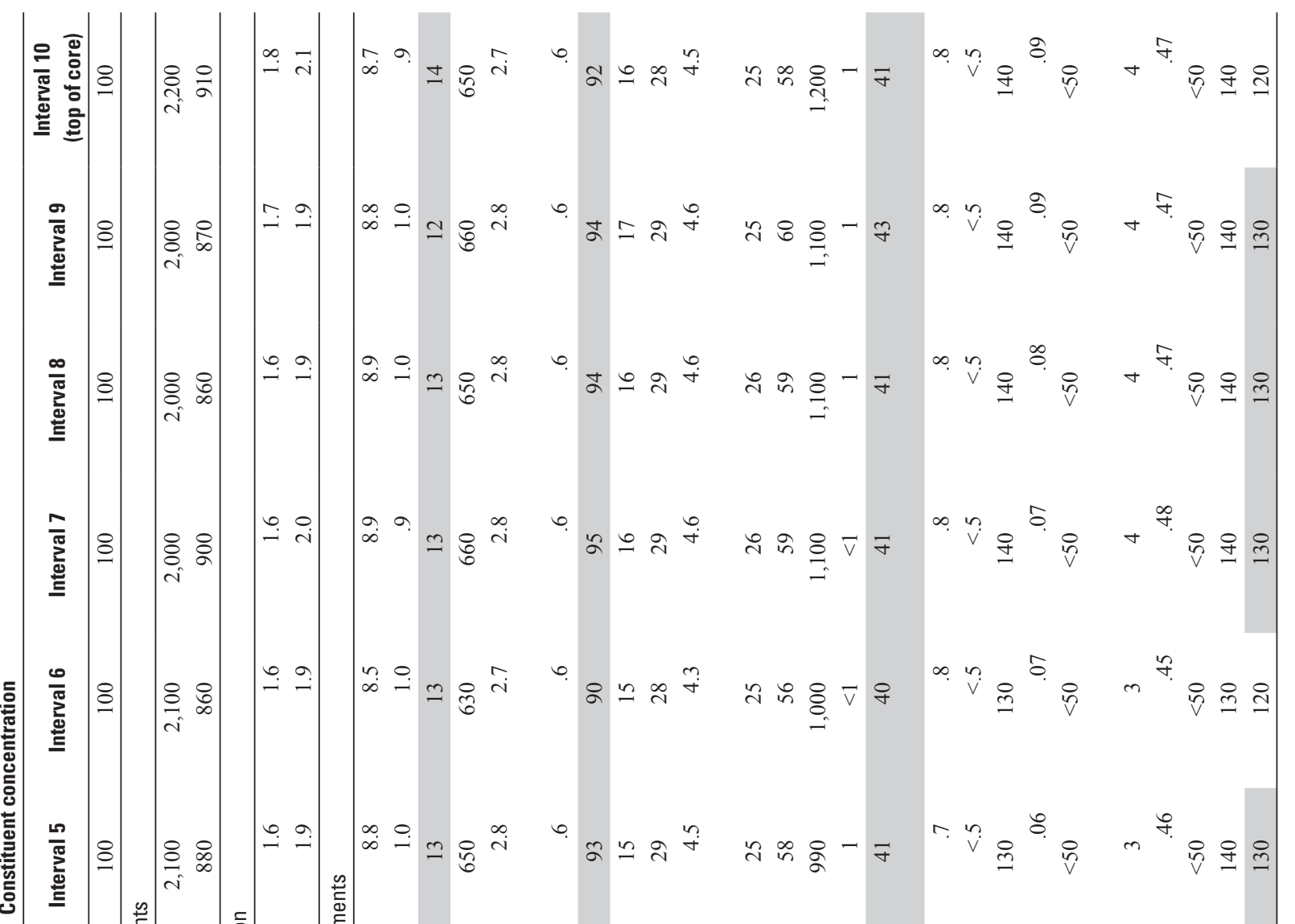

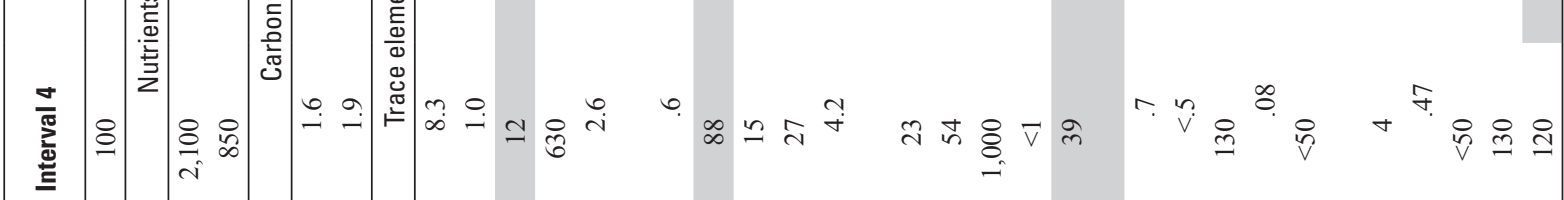

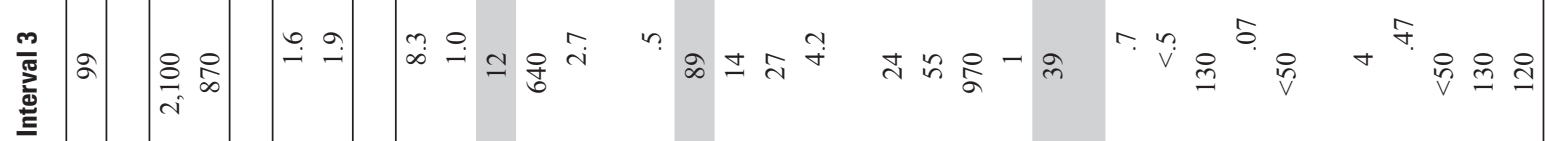

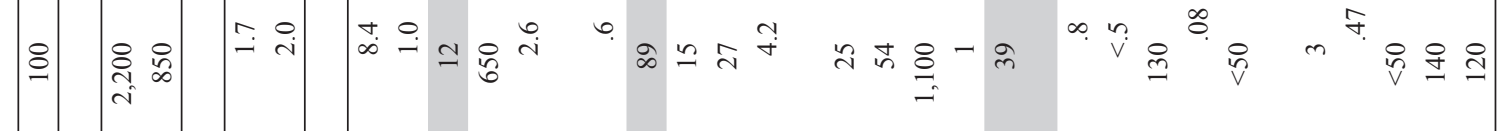

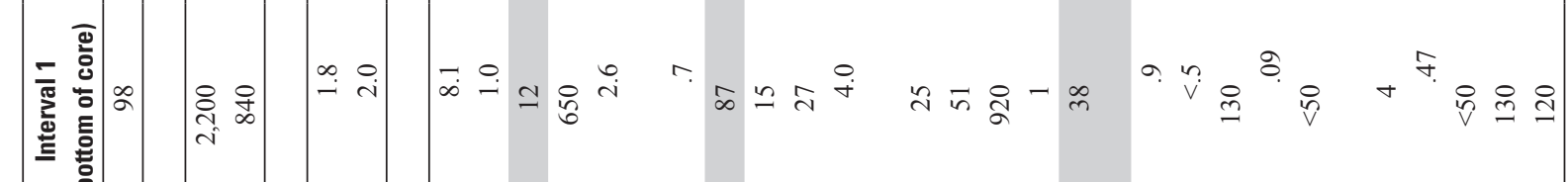

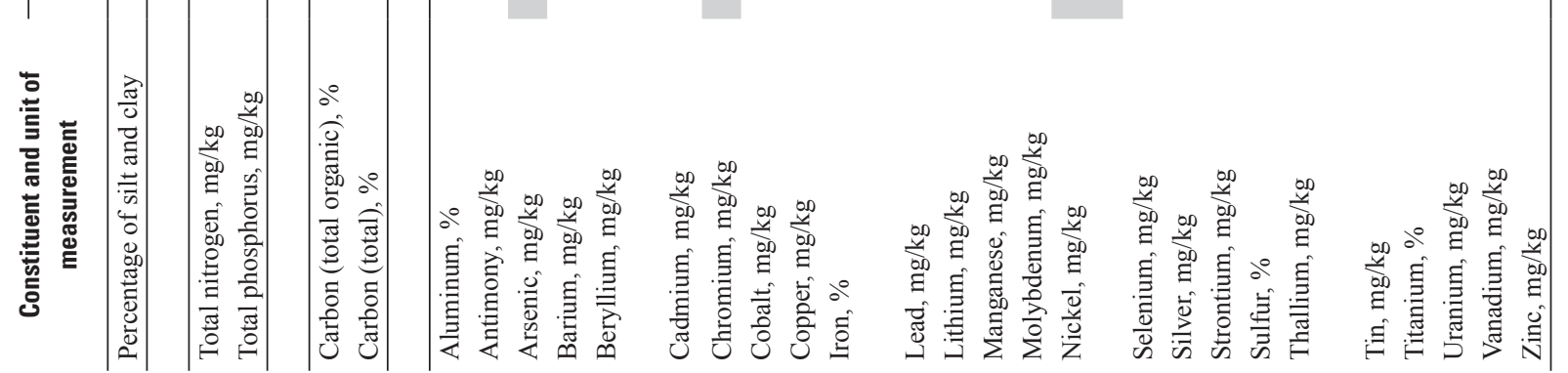




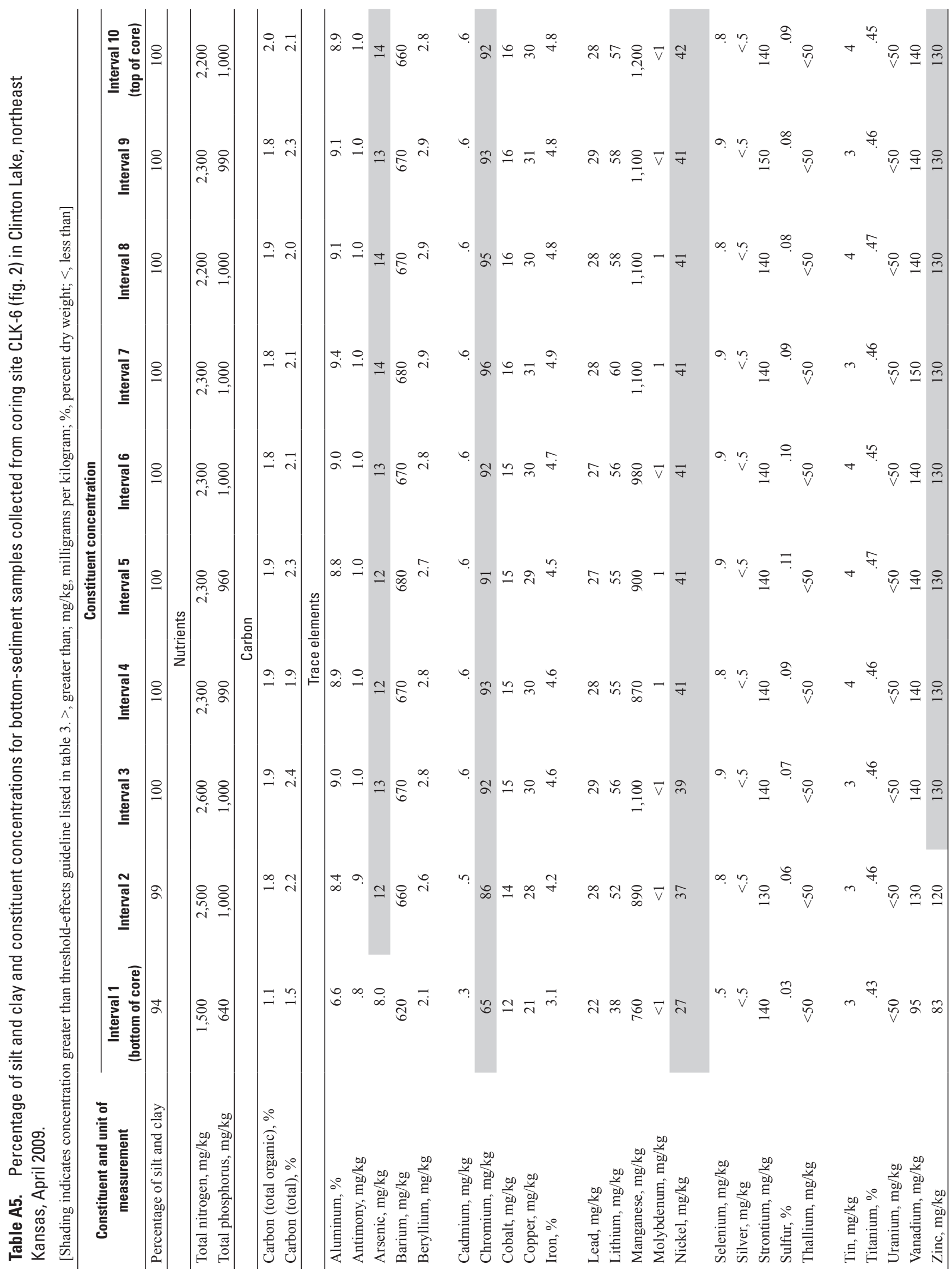


Publishing support provided by: Rolla Publishing Service Center

For additional information concerning this publication, contact: Director, USGS Kansas Water Science Center

4821 Quail Crest Place, Lawrence, KS (785) 842-9909

Or visit the Kansas Water Science Center Web Site at: http://ks.water.usgs.gov 




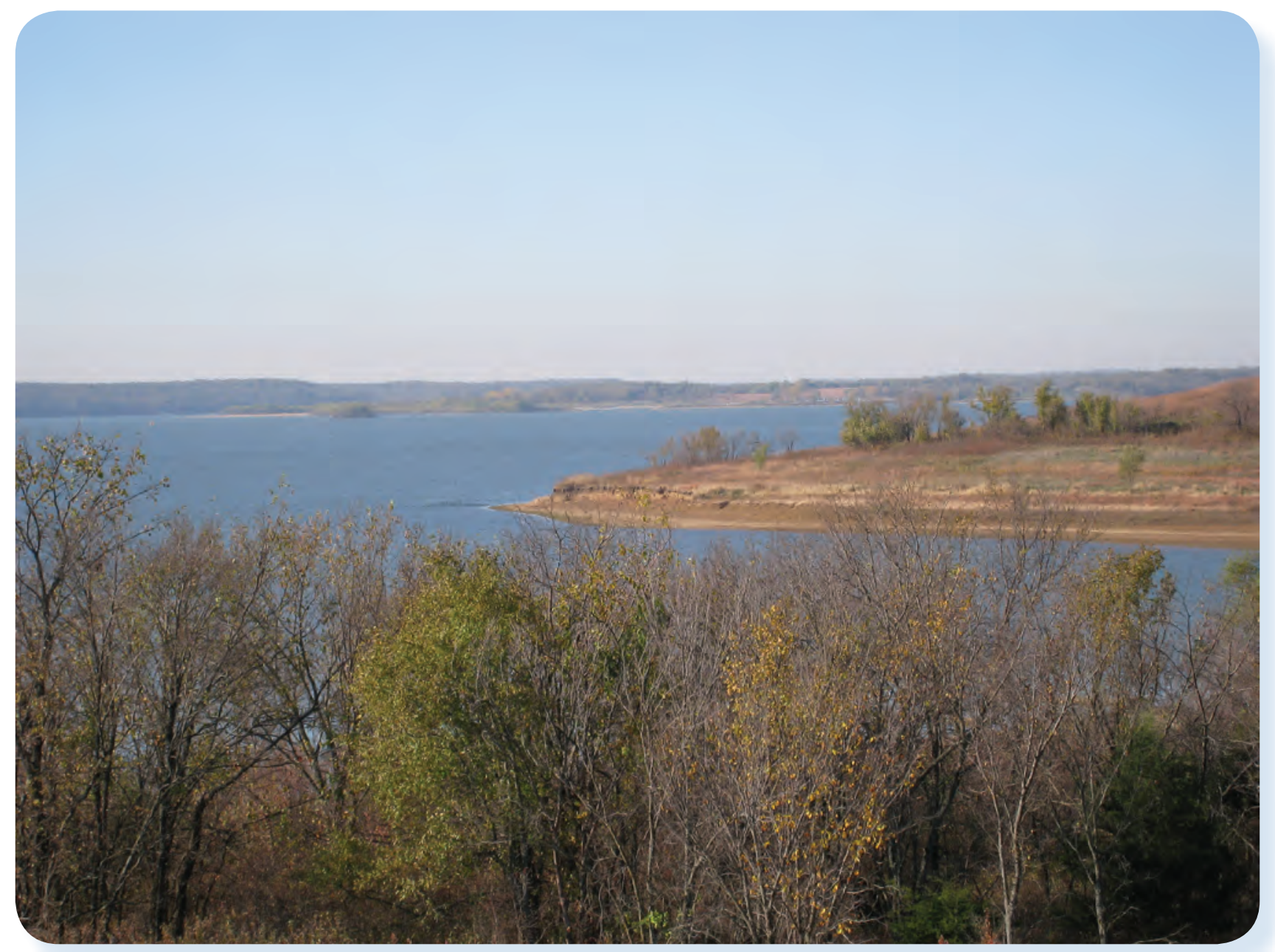

